\title{
Accumulation of germanium (Ge) in plant tissues of grasses is not solely driven by its incorporation in phytoliths
}

\author{
Sabine Kaiser · Stephan Wagner • Christin Moschner • Claudia Funke • \\ Oliver Wiche
}

Received: 30 July 2019/ Accepted: 4 February 2020/Published online: 20 February 2020

(C) The Author(s) 2020

\begin{abstract}
Ge} / \mathrm{Si}$ ratios of plant phytoliths have been widely used to trace biogeochemical cycling of $\mathrm{Si}$. However, until recently, information on how much of the Ge and Si transferred from soil to plants is actually stored in phytoliths was lacking. The aim of the present study is to (i) compare the uptake of $\mathrm{Si}$ and $\mathrm{Ge}$ in three grass species, (ii) localize Ge and Si stored in above-ground plant parts and (iii) evaluate the amounts of $\mathrm{Ge}$ and $\mathrm{Si}$ sequestrated in phytoliths and plant tissues. Mays (Zea mays), oat (Avena sativa) and reed canary grass (Phalaris arundinacea) were
\end{abstract}

Responsible Editor: Karsten Kalbitz.

Electronic supplementary material The online version of this article (https://doi.org/10.1007/s10533-020-00646-x) contains supplementary material, which is available to authorized users.

S. Kaiser $(\bowtie) \cdot$ O. Wiche

Institute for Biosciences, Biology/Ecology Group, TU

Bergakademie Freiberg, Freiberg, Germany

e-mail: sabine.kaiser@tu-freiberg.de

\section{S. Kaiser - C. Funke}

Institute of Experimental Physics, TU Bergakademie

Freiberg, Freiberg, Germany

\section{S. Wagner}

Department of Analytical Chemistry, Helmholtz-Center

for Environmental Research - UFZ, Leipzig, Germany

C. Moschner - O. Wiche

Interdisciplinary Environmental Centre, TU

Bergakademie Freiberg, Freiberg, Germany cultivated in the greenhouse on soil and sand to control element supply. Leaf phytoliths were extracted by dry ashing. Total elemental composition of leaves, phytoliths, stems and roots were measured by ICPMS. For the localization of phytoliths and the determination of $\mathrm{Ge}$ and $\mathrm{Si}$ within leaf tissues and phytoliths scanning electron microscopy (SEM), energy dispersive $\mathrm{x}$-ray spectroscopy (EDX) and laser ablation inductively coupled mass spectrometry (LAICP-MS) was used. The amounts of Si and Ge taken up by the species corresponded with biomass formation and decreased in the order Z. mays $>P$. arundinacea, A. sativa. Results from LA-ICP-MS revealed that $\mathrm{Si}$ was mostly localized in phytoliths, while Ge was disorderly distributed within the leaf tissue. In fact, from the total amounts of Ge accumulated in leaves only $10 \%$ was present in phytoliths highlighting the role of organic matter on biogeochemical cycling of $\mathrm{Ge}$ and the necessity for using bulk $\mathrm{Ge} / \mathrm{Si}$ instead of $\mathrm{Ge} / \mathrm{Si}$ in phytoliths to trace biogeochemical cycling of Si.

Keywords Germanium - Ge/Si ratio - Phytoliths · Poaceae $\cdot$ LA-ICP-MS

\section{Introduction}

Germanium (Ge) is widespread in most rock forming minerals and soil minerals, but with quantities that are 
a factor of roughly 10,000 lower than silicon ( $\mathrm{Si})$. In dependence of the pedogenetic conditions, particularly the soil parent material and weathering intensities, concentrations of $\mathrm{Ge}$ in soils may vary between 0.1 and $15 \mathrm{mg} \mathrm{kg}^{-1}$ (Reimann et al. 2003). However, considering different soil types derived under various pedogenetic conditions the global average concentration in soils is $2 \mathrm{mg} \mathrm{kg}^{-1} \mathrm{Ge}$ (Reimann et al. 2003; Kabata-Pendias 2010; Wiche et al. 2018). During pedogenesis Ge shows remarkable geochemical similarities to that of Si. Due to similar ionic radii (39 pm compared to $\mathrm{Si}=26 \mathrm{pm}$ ) Ge readily substitutes $\mathrm{Si}$ in many primary and secondary soil minerals (Goldschmidt 1926; Shannon 1976; Bernstein 1985). Therefore, germanium $(\mathrm{Ge})$ has been often considered as a "pseudoisotope" of silicon ( $\mathrm{Si}$ ). Indeed, in geochemical research Ge/Si-ratios have been successfully deployed as tracer of Si cycle (Froelich et al. 1985; Derry et al. 2005; Lugolobi et al. 2010; White et al. 2012). However, as a result of laboratory and field experiments, there is evidence that the biogeochemical cycling of Ge is not simply analogous to that of $\mathrm{Si}$ (Pokrovski and Schott 1998). The rationale behind this argument is that, unlike $\mathrm{Si}, \mathrm{Ge}$ exhibits distinct chalcophilic, lithophilic, siderophilic and organophilic behaviour in the environment. Specifically, under most biogeochemically relevant conditions Ge is able to form stable complexes with soil organic matter while for Si this organophilic behaviour seems to be much less pronounced (Pokrovski and Schott 1998).

Besides the movement and transformation of $\mathrm{Ge}$ and $\mathrm{Si}$ within or among biotic and abiotic soil phases, biogeochemical cycling of elements involves the uptake and accumulation of the elements in plant tissues that are subsequently returned to soil through litterfall. It is generally assumed that plants have a strong biological imprint on the biogeochemical cycling of both Si and Ge (Derry et al. 2005; Cornelis et al. 2010; White et al. 2012).

Until recently the transformation of Ge-bearing mineral soil phases and the silicification of plant cells has been extensively studied (Kurtz et al. 2002; Scribner et al. 2006; Piperno 2006; Lugolobi et al. 2010). Nevertheless, there is still a lack in our understanding in the process of $\mathrm{Ge} / \mathrm{Si}$ movement, accumulation and transformation within plants.

The capability of plant species to accumulate $\mathrm{Si} / \mathrm{Ge}$ in their biomass obviously differs among species belonging to the functional groups of monocotyledonous grasses and dicotyledonous forbs, respectively. Plants from the functional group of grasses (Gramineae and Cyperaceae) typically accumulate higher concentrations of both, Ge and $\mathrm{Si}$ in their shoots than forbs (Hodson et al. 2005; Wiche et al. 2018). Some exceptions have been reported for cucumber, sunflower and wax gourd which are $\mathrm{Si}$ accumulating dicots (Yan et al. 2018). The natural silicon content in grasses varies between 0.1 and $10 \%$ of the dry weight depending on the species (Epstein 1999; Ma et al. 2001; Liang et al. 2007). Compared to $\mathrm{Si}$ the concentration of $\mathrm{Ge}$ in grasses is substantially lower ranging between 0.04 to $2.8 \mu \mathrm{g} \mathrm{g}^{-1}$ (Wiche et al. 2018).

Until today, Ge has been neither identified to be essential for plant growth nor as strongly toxic to plants. Plants may accumulate Ge unintentionally during the acquisition of Si. Unlike Ge, Si shows many beneficial effects on plant growth. Silicon improves plants' ability to deal with salt stress, drought stress, temperature fluctuations, radiation and UV-B damage, pathogen attack and metal toxicity (Liang et al. 2007; Balakhnina and Borkowska 2013; Wu et al. 2013; Bakhat et al. 2018; Etesami and Jeong 2018; Katz 2019). The variation in Ge concentrations among species and functional groups originates from physiological differences in the roots, particularly presence or absence of active transport mechanisms or a varying density of the transporters in the root cell membranes (Nikolic et al. 2006; Ma et al. 2007). It is generally assumed that plants take up $\mathrm{Ge}$ in form of the uncharged monomeric germanic acid $\left(\mathrm{Ge}(\mathrm{OH})_{4}\right)$, similar to silicon $\left(\mathrm{Si}(\mathrm{OH})_{4}\right)$. In non-Si-accumulating dicots a concentration-dependent passive uptake of $\mathrm{Si}(\mathrm{OH})_{4}$ and $\mathrm{Ge}(\mathrm{OH})_{4}$ by diffusion across the lipid component of the plasma membrane dominates Si and Ge uptake. However, in grasses, high levels of Ge and $\mathrm{Si}$ are mainly caused by a metabolically active concentration-independent uptake mechanisms (Nikolic et al. 2006) mediated by various influx- and effluxtransporters (Ma et al. 2007; Ma and Yamaji 2008; Mitani et al. 2009; Sparks et al. 2011; Yamaji and Ma 2011; Yamaji et al. 2012) that seem to be not able to distinguish between $\mathrm{Si}$ and $\mathrm{Ge}$.

After taken up by plants the $\mathrm{Si}$ and $\mathrm{Ge}$ are transported along with the transpiration stream into stems and leaves where Si precipitates. It precipitates as amorphous silica bodies and as amorphous Si-plates commonly known as plant opals or phytoliths (Blecker 
et al. 2007). Silicification occurs in the endodermis part of the root of Gramineae during maturation (Perry and Lu 1992; Sahebi et al. 2015; Kumar et al. 2017a). The phytoliths in grasses are embedded in the epidermal layer in form of silica bodies and often arranged in parallel rows by combining different cells (Piperno 2006; Kumar et al. 2017b). Although silicification does occur in other tissues, phytolith density tends to be highest in leaves implying that the formation of biogenic silica is commonly associated to the end of the transpiration stream. The form of phytoliths is influenced by the species, the climate and the biological environment (Piperno 2006). Monocotyledons often form species-specific silica bodies. They occur in various forms (dumbbell-shaped, oblong, butterfly-shaped, club-shaped, etc.), reaching a size of up to $200 \mu \mathrm{m}$ (Piperno 2006). In addition, a thin silica layer formed of thin silica plates is located just below the cuticle of grasses (Yoshida et al. 1962; Ma 2003; Sato et al. 2017). Although still not clear, the formation of species-specific phytoliths indicates that the process of biomineralization is not a simple precipitation as a result of oversaturation but a physiologically regulated process (Kumar et al. 2017a, 2019; Soukup et al. 2017). While there is a large body of literature supporting the importance of phytoliths in biogeochemical cycling of $\mathrm{Si}$, the mechanisms of biomineralization and their relevance for the accumulation of Ge are still not well understood. There appears to be some degree of uncertainty concerning the importance of fractionation between Ge and Si during plant uptake and biomineralization.

Field and laboratory studies indicate that leaf phytoliths isolated from a variety of plant groups have low $\mathrm{Ge} / \mathrm{Si}$ relative to co-existing soil minerals or solutions (Derry et al. 2005; Garvin 2006; Blecker et al. 2007; Delvigne et al. 2009). There is a general consensus that a fractionation of $\mathrm{Ge} / \mathrm{Si}$ occurs during the uptake and/or movement of Ge/Si through the root tissues which supports the use of $\mathrm{Ge} / \mathrm{Si}$ ratios as a tracer of biogenic Si cycling in the terrestrial environment (Derry et al. 2005). However, until recently all interpretations from geochemical field studies available in the literature assume that the Ge transported to shoots is incorporated in phytoliths without discrimination of Ge relative to $\mathrm{Si}$ at this place. To our best knowledge there is no report available in the literature on how much of the Ge taken up is actually stored in phytoliths. However, if proven, this would have major implications for our current understanding of mechanisms and controls on $\mathrm{Ge} / \mathrm{Si}$ fractionation, the biogeochemical cycling of Ge, and the interpretation of field data. Moreover, knowledge on metabolically active incorporation of Ge in biosilica has high relevance for the production of nanostructures suitable for optoelectronic applications due to their unique optical properties (Jeffryes et al. 2008; Qin et al. 2008).

In the present study we conducted a greenhouse experiment in which Zea mays, Avena sativa and Phalaris arundinacea, typical grass species (C3 and C4 representatives) of moist grasslands with high accumulation potential for both $\mathrm{Si}$ and $\mathrm{Ge}$ (Wiche and Heilmeier 2016; Wiche 2016; Wiche et al. 2017) were cultivated on two substrates with differing plant available Ge/Si ratios. Specifically, all plant species were cultivated on sand and on soil. Ge was artificially added to the plants in order to achieve elevated $\mathrm{Ge} / \mathrm{Si}$ levels. In contrast, on substrate for reference plants $\mathrm{Ge}$ was not artificially added which allows to study the uptake behaviour of plants under more realistic environmental conditions. After harvest, Ge/Si present in phytoliths as well as organic plant tissues was measured. Additionally, plant tissues were prepared by high pressure freezing of samples and LA-ICP-MS with the explicit goal to (i) quantify $\mathrm{Ge} / \mathrm{Si}$ present in inorganic and inorganic binding forms as well as (ii) the localization of the elements within the plant tissues.

\section{Materials and methods}

\section{Plant cultivation}

All plant growth experiments were conducted under controlled greenhouse conditions using two different substrates (sand and soil) and three different plant species maize (Zea mays), oat (Avena sativa) and reed canary grass (Phalaris arundinacea).

The sand used in the experiment (quartz sand with $0.1-0.5 \mathrm{~mm}$ grain size, $>95 \% \mathrm{SiO}_{2}$ ) was autoclaved and washed with $0.2 \mathrm{M}$ nitric acid and deionized water prior to the experiment to remove particles and elemental contaminations from the surface of sand grains. The soil was collected from a naturally grassed and unfertilized luvisol on the campus of TU Bergakademie Freiberg, Germany. Covering 
vegetation was stripped off and soil collected from a depth of $10-20 \mathrm{~cm}$. The soil used in the experiment was characterized by physical and chemical properties, typically found in agricultural soils of the Erzgebirge (Saxony) (Table 1).

Phosphorus was determined by calcium acetate lactate (CAL) and measured with ICP-MS. Plant available (mineral) $\mathrm{N}$ in soil was calculated as the sum of $\mathrm{NH}_{4}{ }^{+}-\mathrm{N}$ and $\mathrm{NO}_{3}{ }^{-}-\mathrm{N}$. $\mathrm{NO}_{3}{ }^{-}$and $\mathrm{NH}_{4}{ }^{+}$were extracted from soil samples with deionized water and $1 \mathrm{M} \mathrm{KCl}$, respectively, and photometrically determined according to Bolleter et al. (1961) and Hartley and Asai (1963). K, Mg, Ca and S were extracted by $\mathrm{NH}_{4}$-acetate (pH 5) and measured by ICP-MS.

Total concentrations of $\mathrm{Ge}, \mathrm{Si}$ as well as of selected micronutrients (Fe, $\mathrm{Mn}, \mathrm{Cu}, \mathrm{Zn}, \mathrm{Mo}$ ) in both substrates were analysed by fusing with a mixture of Li-metaborate and Li-tetraborate (1:1) according to Kurtz et al. (2002) and measured by ICP-MS (Kurtz et al. 2002; Wiche et al. 2018). Accuracy was checked by analysis of the geological standards GBW 07406 and GBW 07407 (LGC Standards); results deviated by less than $10 \%$ from certified values.

Additionally, a sequential extraction procedure was applied to identify potential plant available element concentrations in the substrates according to Wiche and Heilmeier (2016). Total concentrations of Ge, Si, selected micronutrients as well as the distribution of the elements in potentially plant available soil fractions are presented in Table 2. In both substrates, concentrations of $\mathrm{Ge}$ and $\mathrm{Si}$ were close to the crustal average of $1.6 \mu \mathrm{g} \mathrm{g}^{-1}$ for Ge (Höll et al. 2007) and $257 \mathrm{mg} \mathrm{g}^{-1}$ for Si (Lane and Burns 1996) and

Table 1 Basic soil properties and potentially plant available concentrations of macronutrients in the soil substrate

\begin{tabular}{ll}
\hline $\mathrm{pH}\left(\mathrm{H}_{2} \mathrm{O}\right)$ & 6.2 \\
$\mathrm{CEC}$ & $9.1 \mathrm{cmol} \mathrm{kg}^{-1}$ \\
$\mathrm{SOM}$ & $7.6 \%$ \\
$\mathrm{~N}$ & $63.9 \mathrm{mg} \mathrm{kg}^{-1}$ \\
$\mathrm{P}$ & $50.2 \mathrm{mg} \mathrm{kg}^{-1}$ \\
$\mathrm{~K}$ & $201 \mathrm{mg} \mathrm{kg}^{-1}$ \\
$\mathrm{Mg}$ & $154 \mathrm{mg} \mathrm{kg}^{-1}$ \\
$\mathrm{Ca}$ & $2100 \mathrm{mg} \mathrm{kg}^{-1}$ \\
$\mathrm{~S}$ & $452 \mathrm{mg} \mathrm{kg}^{-1}$ \\
\hline
\end{tabular}

CEC cation exchange capacity, SOM: soil organic matter (measured by loss of ignition) concomitantly their Ge/Si-ratios were close to the crustal average of $2.4 \mu \mathrm{mol} \mathrm{mol}^{-1}$ (Wiche et al. 2018). In both substrates potential plant available concentrations of Si were similar; however, the sand was characterized by significantly lower concentrations of available Ge concentrations. Specifically, in soil roughly $12 \%$ of Ge was present in exchangeable, acid soluble and oxidizable forms as well as noncrystalline oxides (Table 2) representing important potentially available element forms in soils (Wiche et al. 2016, 2018). In contrast, for sand the Ge observed in these fractions were substantially lower (1.3\%). This experimental design presumes that the plants on sand were solely dependent on external Ge inputs, while the plants on soil could access the Ge present in naturally occurring binding forms (Table 2).

Seeds of maize (Zea mays cv. Badischer Gelber), oat (Avena sativa cv. Scorpion) and reed-canary grass (Phalaris arundinacea cv. Lipaula) were surface sterilized by washing the seeds with $0.5 \%$ sodium hypochlorite $(\mathrm{NaOCl})$ for $3 \mathrm{~min}$ followed by carefully rinsing with deionized water and allowed to germinate in petri dishes in a climate chamber at $20{ }^{\circ} \mathrm{C}$. After germination the seedlings of each plant species were planted in 32 plastic pots ( $3 \mathrm{~L}$ total volume) filled either with sand or soil substrate. Due to expected differences in plant size and biomass formation of the different plant species for oat and maize only one seedling was placed in each pot, while for reed canary grass 20 plant individuals were transplanted into each pot (one pot $=$ one experimental unit $(\mathrm{eu})$ ). The pots were incubated in a greenhouse with a 15 -h photoperiod (15-h day, 9-h night), $18-30{ }^{\circ} \mathrm{C}$ (night/daytemperature), relative humidity $65 \%$, and photosynthetically active photon flux density of $600 \mu \mathrm{mol} \mathrm{m} \mathrm{m}^{-2} \mathrm{~s}^{-1}$. During a time period of eight weeks, all plants received weekly $150 \mathrm{ml}$ of nutrient solutions that contained $4 \mathrm{mM} \mathrm{KNO}_{3}$, $1 \mathrm{mM} \mathrm{MnCl}_{2}, 3.5 \mathrm{mM} \mathrm{NH} \mathrm{NO}_{3}, 2 \mathrm{mM} \mathrm{Ca}\left(\mathrm{NO}_{3}\right)_{2}$, $2 \mathrm{mM} \mathrm{CaCl}, 2 \mathrm{mM} \mathrm{MgSO}_{4}, 1 \mathrm{mM} \mathrm{K} \mathrm{K}_{2} \mathrm{HPO}_{4}$, $5 \mathrm{mM} \mathrm{H}_{3} \mathrm{BO}_{3}, 0.03 \mathrm{mM} \mathrm{CuSO}_{4}, 0.07 \mathrm{mM} \mathrm{ZnSO}$, $0.015 \mathrm{mM}\left(\mathrm{NH}_{4}\right)_{6}\left(\mathrm{Mo}_{7} \mathrm{O}_{24}\right)$, and $1.4 \mathrm{mM}$ ethylenediaminetetraacidicacid-iron (Fe-EDTA). Additionally to the nutrients solutions, after the first two weeks of plant growth, the plants on both substrates received weekly $200 \mathrm{ml}$ of treatment solutions containing either 5,10 or $50 \mu \mathrm{mol} \mathrm{L}{ }^{-1} \mathrm{Ge}$ in form of $\mathrm{Ge}(\mathrm{OH})_{4}$ or no Ge as a reference. The Ge concentrations in the treatment solutions were roughly a factor of 10 
Table 2 Total concentrations of $\mathrm{Ge}, \mathrm{Si}, \mathrm{Al}$ and selected essential trace elements in the substrates used in the greenhouse experiment and concentrations in six operationally defined fractions according to Wiche and Heilmeier (2016)

\begin{tabular}{lllllclc}
\hline Substrate & Fraction & $\mathrm{Si}\left(\mathrm{mg} \mathrm{g}^{-1}\right)$ & $\mathrm{Ge}\left(\mu \mathrm{g} \mathrm{g}^{-1}\right)$ & $\mathrm{Ge} / \mathrm{Si}\left(\mu \mathrm{mol} \mathrm{mol}^{-1}\right)$ & $\mathrm{Al}\left(\mathrm{mg} \mathrm{g}^{-1}\right)$ & $\mathrm{Fe}\left(\mathrm{mg} \mathrm{g}^{-1}\right)$ & $\mathrm{Mn}\left(\mathrm{mg} \mathrm{g}^{-1}\right)$ \\
\hline Soil & Total & $243.4 \pm 10.9$ & $1.79 \pm 0.03$ & $2.84 \pm 0.06$ & $53.1 \pm 2.4$ & $24.6 \pm 1.2$ & $5.9 \pm 2.0$ \\
& Fraction 1 & $0.062 \pm 0.009$ & $0.007 \pm 0.001$ & $49.9 \pm 5.8$ & $0.005 \pm 0.001$ & $0.004 \pm 0.001$ & $0.051 \pm 0.006$ \\
& Fraction 2 & $0.054 \pm 0.004$ & $0.022 \pm 0.001$ & $160 \pm 9.8$ & $0.081 \pm 0.006$ & $0.019 \pm 0.002$ & $0.032 \pm 0.004$ \\
& Fraction 3 & $0.922 \pm 0.043$ & $0.120 \pm 0.014$ & $49.3 \pm 5.6$ & $1.679 \pm 0.194$ & $0.481 \pm 0.080$ & $0.389 \pm 0.016$ \\
& Fraction 4 & $0.611 \pm 0.042$ & $0.079 \pm 0.007$ & $54.6 \pm 9.6$ & $2.968 \pm 0.183$ & $6.794 \pm 0.370$ & $0.026 \pm 0.004$ \\
& Fraction 5 & $1.637 \pm 0.071$ & $0.049 \pm 0.005$ & $11.9 \pm 1.5$ & $1.067 \pm 0.071$ & $6.216 \pm 0.293$ & $0.025 \pm 0.002$ \\
& Residual & $240.1 \pm 0.820$ & $1.51 \pm 0.02$ & $2.44 \pm 0.1$ & $47.3 \pm 5.2$ & $13.1 \pm 1.2$ & $5.4 \pm 0.2$ \\
Sand & Total & $264.6 \pm 23.3$ & $1.58 \pm 0.02$ & $2.31 \pm 0.08$ & $13.8 \pm 1.7$ & $8.3 \pm 1.3$ & $2.6 \pm 0.4$ \\
& Fraction 1 & $0.057 \pm 0.013$ & $<0.005$ & n.a. & $0.001 \pm 0.002$ & $<0.0005$ & $0.004 \pm 0.001$ \\
& Fraction 2 & $0.078 \pm 0.009$ & $0.006 \pm 0.002$ & $31.2 \pm 2.2$ & $0.009 \pm 0.005$ & $0.008 \pm 0.002$ & $0.003 \pm 0.001$ \\
& Fraction 3 & $0.440 \pm 0.057$ & $<0.005$ & n.a. & $0.014 \pm 0.003$ & $0.009 \pm 0.003$ & $0.119 \pm 0.108$ \\
& Fraction 4 & $0.090 \pm 0.039$ & $0.015 \pm 0.003$ & $73.8 \pm 18.8$ & $0.525 \pm 0.238$ & $1.043 \pm 0.256$ & $0.004 \pm 0.003$ \\
& Fraction 5 & $0.431 \pm 0.256$ & $0.059 \pm 0.014$ & $69.5 \pm 28.6$ & $0.219 \pm 0.128$ & $3.501 \pm 0.701$ & $0.016 \pm 0.005$ \\
& Residual & $263.5 \pm 1.2$ & $1.49 \pm 0.04$ & $2.19 \pm 0.21$ & $13.0 \pm 0.2$ & $3.7 \pm 0.4$ & $2.4 \pm 0.2$ \\
\hline
\end{tabular}

Fraction 1 = mobile/exchangeable elements; Fraction $2=$ acid soluble elements; Fraction $3=$ elements in oxidizable matter; Fraction $4=$ non-crystalline oxides; Fraction $5=$ crystalline oxides. Residual concentrations (Fraction 6) are calculated as the difference between total concentrations and fractions $1-5$

The values are means of 10 replicates for each substrate

$\left(5 \mu \mathrm{mol} \mathrm{L}{ }^{-1} \mathrm{Ge}\right)$ to $100\left(50 \mu \mathrm{mol} \mathrm{L}{ }^{-1} \mathrm{Ge}\right)$ higher compared to naturally occurring soil solution concentrations (Wiche et al. 2016), and therefore, simulated experimental conditions of elevated $\mathrm{Ge} / \mathrm{Si}$ ratios, while references $\left(0 \mu \mathrm{mol} \mathrm{L}{ }^{-1} \mathrm{Ge}\right)$ were set up to simulate natural growth conditions. Ge solutions were prepared from a $10 \mathrm{mM} \mathrm{Ge}(\mathrm{OH})_{4}$ stock solution that was freshly prepared by dissolving $\mathrm{GeO}_{2}$ (Sigma Aldrich) in deionized water. In total during plant cultivation all plants received 6, 12 and $60 \mu \mathrm{mol} \mathrm{Ge}$ regardless on which substrates the plants were cultivated. In both substrates, Si was not artificially added, since it was sufficiently available for the plants (Table 2). The reference plants were not artificially treated with Ge solutions but were exposed to the initial Ge/Si concentrations of the substrates (Table 2), whilst plants treated with Ge solutions were exposed to artificially elevated $\mathrm{Ge} / \mathrm{Si}$-ratios. All treatments were fourfold replicated in a fully-randomized design. Shortly after a few plants of $A$. sativa set seed, all plants were cut $2 \mathrm{~cm}$ above the ground and carefully washed with $1 \% \mathrm{HNO}_{3}$ and distilled water to remove particles and element contaminations. Each plant of the 96 pots was separated into roots, leaves and stems.
From each plant the leaves from the bottom, the middle and the top were carefully mixed to make sure to get representative samples for each plant. One half of the samples was freeze-dried and stored at $10{ }^{\circ} \mathrm{C}$ until getting analysed by laser ablation inductively coupled plasma mass spectrometry (LA-ICP-MS) and scanning electron microscopy (SEM). The leftover material of each sample was cooled down with fluid nitrogen and stored at $-20{ }^{\circ} \mathrm{C}$ in the fridge before being further processed for total element analysis and the determination of fractions of organically bound $\mathrm{Ge}$ and $\mathrm{Ge} / \mathrm{Si}$ in phytoliths. Fluorescence microscopy investigations were performed with fresh plant material.

Total element concentrations in plants

The frozen plants were dried to total dryness at $60{ }^{\circ} \mathrm{C}$ for $48 \mathrm{~h}$. Nearly half of the dry material was ground to a fine powder with an ultracentrifugation mill (type ZM1000, Retsch, Germany). The rest of the dry material was used for the extraction of phytoliths and the determination of organically bound $\mathrm{Ge}$ (see section below). A subsample of $100 \mathrm{mg}$ of the fine powdered 
plant material was used for microwave digestion (Ethos plus 2, MLS) with $3 \mathrm{ml}$ nitric acid and $0.1 \mathrm{ml}$ hydrofluoric acid (Wiche 2016). Concentrations of Ge and Si were measured at the Institute of Biosciences, TU Bergakademie Freiberg, Germany by means of ICP-MS (Xseries 2, Thermo scientific) with $10 \mu \mathrm{g}^{-1}$ rhodium and rhenium as internal standards. Calibration solutions $\left(0.01-100 \mu \mathrm{g}^{-1}\right)$ were prepared by adequate dilution of a multi-element stock standard solution (Merck). Accuracy was checked by analysis of the certified reference standards NCS ZC73032 (Celery) and NCS ZC73030 (Wheat; China National Analysis Center for Iron and Steel 2014); all results deviated by less than $10 \%$ from certified values. The graphs were created with Origin 2016.

Localization of phytoliths in leaves using fluorescence microscopy

The distribution of phytoliths in leaves of maize and oat plants (without artificial Ge treatment) were investigated on the adaxial site of the leaf. Fluorescence microscopy was performed by using a Biorevo BZ9000 device (KEYENCE) with the filter "OP79304 SB filter DAPI-BP" (EX $377 \mathrm{~nm} \pm 25 \mathrm{~nm} /$ EM: $447 \mathrm{~nm} \pm 30 \mathrm{~nm}$ ). The confocal mode was used to focus the focal plane of phytoliths. The $\mathrm{NaOH}-$ treatment method based on Soukup et al. (2014) and fresh leaves were used for the visualization of phytoliths ( $\mathrm{pH}=12)$.

Localization of Ge and $\mathrm{Si}$ in leaves using Laser Ablation ICP-MS (LA-ICP-MS)

For the localization of Ge and Si freeze-dried leaves of maize and oat plants (reference plants without artificial Ge treatment and plants treated with $50 \mu \mathrm{mol} \mathrm{L}{ }^{-1} \mathrm{Ge}$ ) were fixed on aluminum sample holders. Laser Ablation Inductively Coupled Plasma Mass Spectrometry (LA-ICP-MS) was conducted at the Helmholtz-Center for Environmental Research using a SpectroMS device (Spectro, Germany) allowing simultaneous detection of several elements. The laser ablation system consisted of the sample chamber HelEX II and a $193 \mathrm{~nm} \mathrm{G2}$ excimer laser (Teledyne Cetac, USA). Argon was used as carrier gas at a flow rate of $11 \mathrm{~min}^{-1}$. The laser energy was $25 \%$ at a repetition rate of $100 \mathrm{~Hz}$ and a fluence of $0.76 \mathrm{~mJ} \mathrm{~cm}^{-2}$. For the ICP-MS measurement of elements the following conditions were used: plasma power $900 \mathrm{~W}$, Coolant flow $121 \mathrm{~min}^{-1}$, auxiliary gas flow $2.31 \mathrm{~min}^{-1}$, total integration time $1000 \mathrm{~ms}$, base interval $200 \mathrm{~ms}$. The simultaneously monitored isotopes were ${ }^{74} \mathrm{Ge},{ }^{28} \mathrm{Si}$ and ${ }^{13} \mathrm{C}$, the used spot size for LA-ICP-MS was $35 \mu \mathrm{m}$ and the scan speed $35 \mu \mathrm{m} \mathrm{s}^{-1}$. To account for instrument sensitivity decrease during analysis, NIST 610 glass standard was run before and after analysis of a leaf. The relative change in signal intensity of the NIST 610 was used to correct signal intensities drift during the analysis. Signal intensities were recorded as time resolved signal. All intensity data was treated according to the following workflow: (1) Normalization to C-intensity for correction of different sample thickness, (2) Calculation of relative intensities for ${ }^{28} \mathrm{Si}$ and ${ }^{74} \mathrm{Ge}$ to be able to compare the data, (3) Subsequently the analysis time was converted into $x-y$ data using the laser $\log$ file were $\mathrm{x}-\mathrm{y}$ position and time has been stored. The conversion was done by IOLITE software package (version 3.4). The $\mathrm{x}-\mathrm{y}$ data and relative intensity data were plotted as 2D map. Maps indicate always relative intensity data.

\section{Combustion of plant leaves}

Prior to the phytolith extraction nickel crucibles $(99.6 \% \mathrm{Ni})$ were cleaned with $10 \% \mathrm{HCl}$ and $10 \%$ $\mathrm{H}_{2} \mathrm{O}_{2}$ for $1 \mathrm{~h}$ and subsequently heated up to $500{ }^{\circ} \mathrm{C}$ in a muffle furnace for one hour. Dried leaves of each of the three grasses (reference plants without artificial Ge treatment and plants treated with $50 \mu \mathrm{mol} \mathrm{L}{ }^{-1} \mathrm{Ge}$ ) were placed inside the crucible and were calcined at $500{ }^{\circ} \mathrm{C}$ for $4 \mathrm{~h}$. After cooling down the ash was transferred into sample tubes by adding $10 \mathrm{ml}$ of $1 \% \mathrm{HNO}_{3}$. The sample tubes were slowly shaken for one hour. The solutions were subsequently filtered through $200 \mathrm{~nm}$ cellulose mixed ester (CME) filter membranes (MERCK MILLIPORE). Each filter was washed three times with deionized water. A blank filter without ash was processed as reference. The membrane filters with the adhering phytoliths were dried at $60{ }^{\circ} \mathrm{C}$ for $48 \mathrm{~h}$ and weighed. After cooling, the filters of three out of four replicates were placed into microwave digestion tubes (Ethos plus 2, MLS) and totally dissolved by using a mixture of $\mathrm{HNO}_{3}, \mathrm{H}_{2} \mathrm{O}_{2}$ and HF (Wiche et al. 2016). The last remaining filter with adhering phytoliths was later used for microscopy and EDX measurements. Concentrations of $\mathrm{Si}$ and $\mathrm{Ge}$ 
in the resulting solutions and the filtrates were measured by ICP-MS using $10 \mu \mathrm{g}^{-1}$ rhodium and rhenium as internal standards.

\section{Microscopy observation and EDX measurements}

Structure and elemental composition of phytoliths on the filters (see above) were explored using scanning electron microscopy (SEM) and Energy dispersive X-ray spectroscopy (EDX); a "FEI Helios NanoLab 600i" at the Institute of Experimental Physics, TU Bergakademie Freiberg, Germany. X-ray microanalysis was performed on the same instrument with an EDX-detector of EDAX [Apollo X Silicon Drift Detetector (SDD) Series]. The acceleration voltage therefore was $10 \mathrm{kV}$. Following spectral lines were used: $\mathrm{Ge} \mathrm{L}_{\alpha}=1.186 \mathrm{keV}, \quad \mathrm{Si} \quad \mathrm{K}_{\alpha}=1.740 \mathrm{keV}$, $\mathrm{O} \mathrm{K}_{\alpha}=0.523 \mathrm{keV}$ and $\mathrm{C} \mathrm{K}_{\alpha}=0.282 \mathrm{keV}$. The filters were fixed directly on the sample holder by using clamps (no electrically conductive coating). To visualize the surface of leaves the same electron microscope was used. Plant samples were fixed directly on sample holders with silver conductivity paste.

Statistical analysis

Differences in element concentrations and contents in the biomass (calculated as biomass $\times$ concentration) of a certain plant part among the investigated species were identified by one-way analysis of variance (ANOVA) using IBM SPSS Statistics 25. For each of the analysis, residuals were tested for homogeneity of variances by using Levene's test. In case of significant differences in the variances between the selected groups a log-transformation was performed. At variance homogeneity, an ANOVA with a Scheffé post-hoc test was performed in order to test for significant differences among the groups at $\alpha=0.05$. In case of no homogeneity in variances between groups a Kruskal-Wallis test with Bonferroni correction for multiple tests was used. Differences in element concentrations among plant parts within a certain species were identified by a nested ANOVA with plant parts as paired subgroups within the investigated plant species followed by a Bonferroni post-hoc test.

\section{Results}

Plant growth and total element concentrations in different plant parts

Reference plants without artificial Ge treatment accumulated 0.06-1.16 $\mu \mathrm{g} \mathrm{g}^{-1} \mathrm{Ge}$ and 1.61-30.2 $\mathrm{mg} \mathrm{g}^{-1}$ $\mathrm{Si}$ in the plant biomass with highest concentrations of Ge and in stems of P. arundinacea (Table 3). Compared to $\mathrm{Ge}$, Si concentrations in the investigated reference plant species was characterized by low variability among species, particularly in aboveground tissues. Specifically, considering all species there were small differences in $\mathrm{Si}$ concentrations between leaves and stems. However, all species were characterized by significantly higher concentrations of $\mathrm{Si}$ in roots than in shoots. Also, we found no significant differences in Si concentrations among the investigated plant species, except for the stems. Stems of $Z$. mays contained significantly lower concentrations of Si $\left(1.61 \mu \mathrm{g} \mathrm{g}^{-1}\right)$, compared to A. sativa $\left(2.42 \mu \mathrm{g} \mathrm{g}^{-1}\right)$ and $P$. arundinacea $\left(3.44 \mu \mathrm{g} \mathrm{g}^{-1}\right)$. In contrast, the outcome of the greenhouse study showed marked differences in the Ge concentrations of different above-ground parts and this variability in Ge concentrations was clearly depended on the investigated reference species. Ge in roots was not affected by plant species showing no significant difference among the species (Table 3). Except for oat, the highest Ge concentration was found in the stems (Z. mays: $0.84 \mu \mathrm{g}^{-1} ; P$. arundinacea: $1.17 \mu \mathrm{g} \mathrm{g}^{-1}$ ), followed by roots (Z. mays: $0.62 \mu \mathrm{g} \mathrm{g}^{-1}, P$. arundinacea: $0.54 \mu \mathrm{g} \mathrm{g}^{-1}$ ) and leaves (Z. mays: $0.29 \mu \mathrm{g} \mathrm{g}^{-1} ; P$. arundinacea: $\left.0.07 \mu \mathrm{g} \mathrm{g}^{-1}\right)$. In A. sativa the highest concentration was found in roots $\left(0.62 \mu \mathrm{g} \mathrm{g}^{-1}\right)$, followed by leaves $\left(0.33 \mu \mathrm{g} \mathrm{g}^{-1}\right)$ and stems $\left(0.16 \mu \mathrm{g} \mathrm{g}^{-1}\right)$. For Z. mays there was no significant difference in Ge concentrations between the plant parts, while the two other plant species showed clear differences (Table 3). A comparison of Ge concentrations among a certain plant tissue between the species revealed significant differences in the Ge concentration in leaves and stems. The $\mathrm{Ge} / \mathrm{Si}$ ratio in dry biomass of references ranged from 10.14 to $203.14 \mu \mathrm{mol} \mathrm{mol}^{-1}$ with significant differences between the species in leaves and stems. The highest ratios were found in stems of $Z$. mays $\left(203.14 \mu \mathrm{mol} \mathrm{mol}^{-1}\right)$ and $P$. arundinacea (128.36 $\left.\mu \mathrm{mol} \mathrm{mol}{ }^{-1}\right)$. 
Table 3 Concentration of Ge and Si in different plant parts of soil-grown reference plants $(\mathrm{n}=4)$

\begin{tabular}{lllll}
\hline Plant species & Plant parts & $\mathrm{Ge}\left(\mu \mathrm{g} \mathrm{g}^{-1}\right)$ & $\mathrm{Si}\left(\mathrm{mg} \mathrm{g}^{-1}\right)$ & $\mathrm{Ge} / \mathrm{Si}\left(\mu \mathrm{mol} \mathrm{mol}^{-1}\right)$ \\
\hline Z. mays & Leaves & $0.291 \pm 0.061^{\mathrm{A}}$ & $3.757 \pm 1.234$ & $36.369 \pm 9.292$ \\
& Stems & $0.840 \pm 0.434$ & $1.615 \pm 0.144$ & $203.145 \pm 98.692$ \\
& Roots & $0.513 \pm 0.020$ & $8.408 \pm 2.117$ & $31.870 \pm 12.011$ \\
& p value & $0.319^{\mathrm{I}}$ & $0.018^{\mathrm{I}}$ & $0.103^{\mathrm{I}}$ \\
A. sativa & Leaves & $0.330 \pm 0.078^{\mathrm{A}}$ & $4.867 \pm 2.201$ & $38.027 \pm 10.731$ \\
& Stems & $0.156 \pm 0.019^{\mathrm{B}}$ & $2.417 \pm 0.351$ & $26.052 \pm 3.826$ \\
& Roots & $0.622 \pm 0.113$ & $30.262 \pm 10.172$ & $12.087 \pm 4.876$ \\
P. arundinacea & p value & $0.005^{\mathrm{I}}$ & $0.007^{\mathrm{I}}$ & $0.053^{\mathrm{I}}$ \\
& Leaves & $0.067 \pm 0.004$ & $3.042 \pm 0.783$ & $10.140 \pm 2.246$ \\
& Stems & $1.166 \pm 0.353^{\mathrm{B}}$ & $3.442 \pm 0.705$ & $128.364 \pm 17.855$ \\
& Roots & $0.540 \pm 0.055$ & $12.422 \pm 3.484$ & $20.238 \pm 4.640$ \\
p values (species) & p value & $0.241^{\mathrm{I}}$ & $0.059^{\mathrm{I}}$ & $0.008^{\mathrm{I}}$ \\
& Leaves & $0.013^{\mathrm{II}}$ & $0.913^{\mathrm{II}}$ & $0.030^{\mathrm{II}}$ \\
& Stems & $0.011^{\mathrm{II}}$ & $0.031^{\mathrm{II}}$ & $0.039^{\mathrm{II}}$ \\
& Roots & $0.913^{\mathrm{II}}$ & $0.104^{\mathrm{II}}$ & $0.234^{\mathrm{II}}$ \\
\hline
\end{tabular}

Indicated are the mean values \pm standard error

Significant differences between the species considering a certain plant part (capital letters) are identified by a Kruskal-Wallis test. Significant differences between plant parts within a certain species (small letters) were identified by a nested ANOVA followed by a Bonferroni post-hoc test

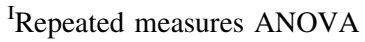

${ }^{\mathrm{II}}$ Kruskal-Wallis test. $\alpha=0.05$

${ }^{\mathrm{A}, \mathrm{B}}$ Significant between species

Artificial addition of Ge to the plants significantly increased the Ge concentrations in all plant tissues and plant species, irrespective the substrate type used for cultivation (Fig. 1). In all treatment groups (reference plants and artificial Ge-treated plants) developed without observable deficiency symptoms, alteration of biomass formation or signs of Ge-toxicity (see Online Resource 1). However, compared to plants cultivated on sand, plants on soil achieved a significant higher total biomass in all treatment groups with $\mathrm{Ge}$ addition as well as the reference plants (Table 3), most probably due to unexpected below-ground root-soilinteractions during nutrient acquisition.

Plants with artificial Ge treatment of $5 \mu \mathrm{mol} \mathrm{L}{ }^{-1}$ $\mathrm{Ge}$ in the treatment solution accumulated $0.76-50.78 \mu \mathrm{g}$ Ge per experimental unit (eu) in the plant biomass (Online Resource 1).With artificial Ge treatment of $10 \mu \mathrm{mol} \mathrm{L}{ }^{-1}$ Ge $1.06-147.03 \mu \mathrm{g} \mathrm{eu}^{-1}$ Ge and with $50 \mu \mathrm{mol} \mathrm{L}{ }^{-1}$ Ge 5.41-431.22 $\mu \mathrm{g} \mathrm{eu}^{-1}$ Ge accumulated in the biomass (Online Resource 1). The highest Ge amounts in the biomass of roots and leaves were in all treatments of $P$. arundinacea on sand, where as in stems the highest Ge amounts were found in all treatments of Z. mays. In all plant species $\mathrm{Si}$ was predominantly accumulated in the roots (0.65-16.32 $\left.\mathrm{mg} \mathrm{eu}^{-1}\right)$, irrespective the treatment with Ge and the substrate used. Also, considering other plant tissues, the leaves and stems, respectively, an addition of different Ge concentrations $\left(5 \mu \mathrm{mol} \mathrm{L}{ }^{-1}\right.$, $10 \mu \mathrm{mol} \mathrm{L}{ }^{-1}$ und $50 \mu \mathrm{mol} \mathrm{L}{ }^{-1}$ ) in the treatment solution showed no significant effects on silicon uptake (stems: $\quad 0.37-4.63 \mathrm{mg} \quad \mathrm{eu}^{-1}$; leaves: 0.45-3.06 $\mathrm{mg} \mathrm{eu}^{-1}$ ). The concentration of Si varied from 1.34 to $30.26 \mathrm{mg} \mathrm{g}^{-1}$ with the highest $\mathrm{Si}$ values in the roots (Fig. 1). A significant dependence of $\mathrm{Si}$ in plants on Ge treatment is only apparent in roots ( $p$ value $=0.001)$ and stem $(\mathrm{p}$ value $=0.015)$ of $Z$. mays on sand; stems of $P$. arundinacea on sand ( $\mathrm{p}$ value $=$ 0.029 ) and stems of A. sativa on soil substrate ( $\mathrm{p}$ value $=0.009$ )

However, there were marked differences in the Ge concentrations in plant tissues of all three plant species 

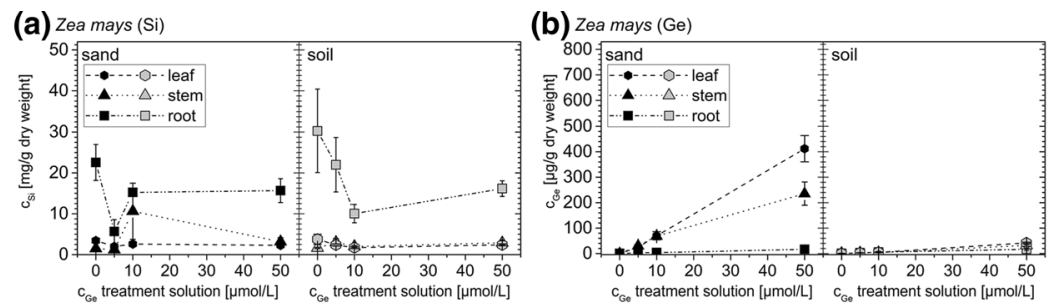

(c) Zea mays (Ge/Si)

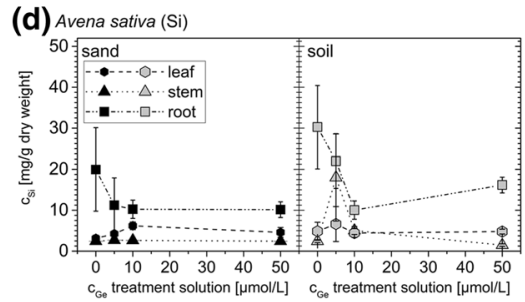

(e) Avena sativa (Ge)
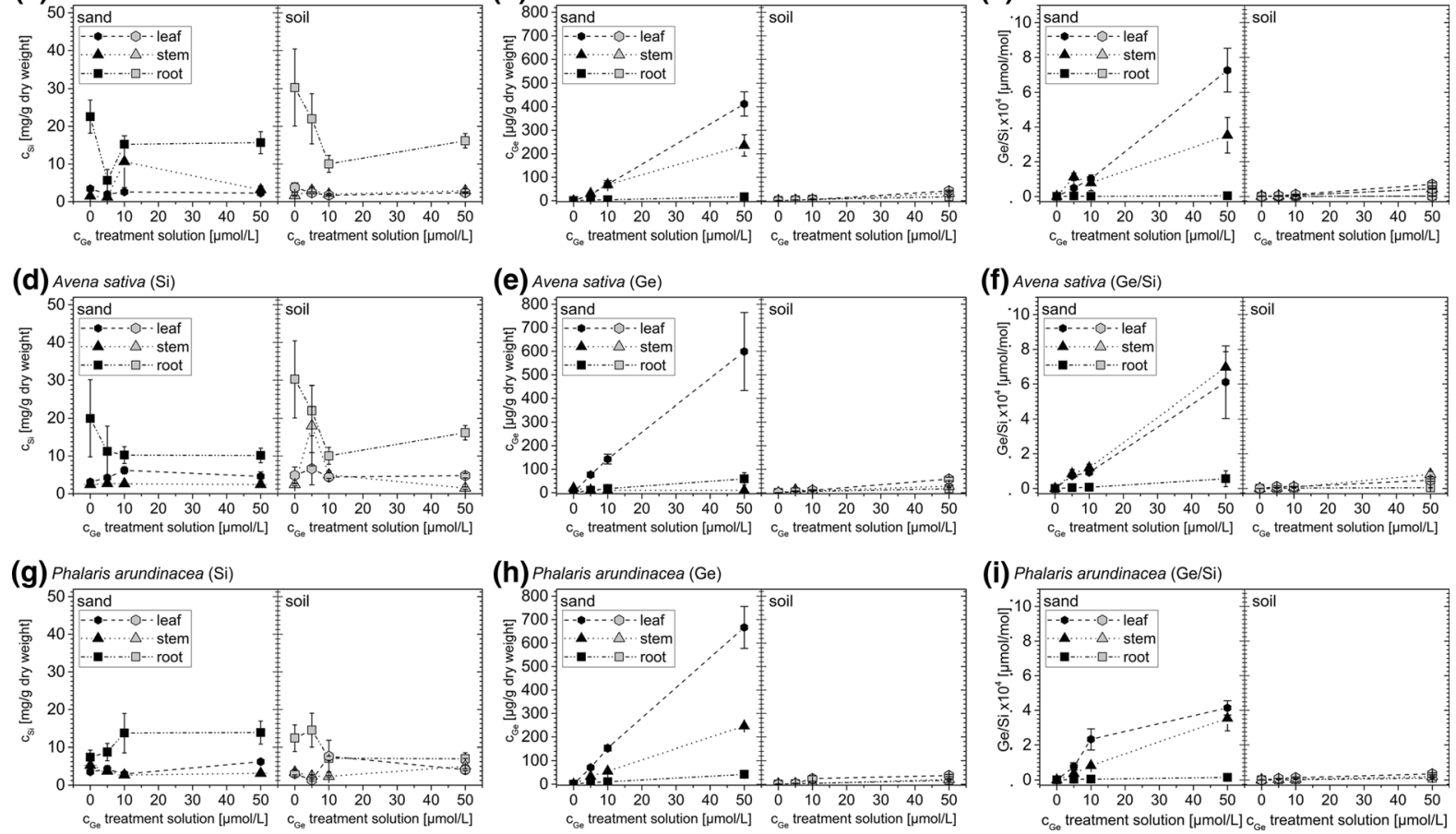

(h) Phalaris arundinacea (Ge)

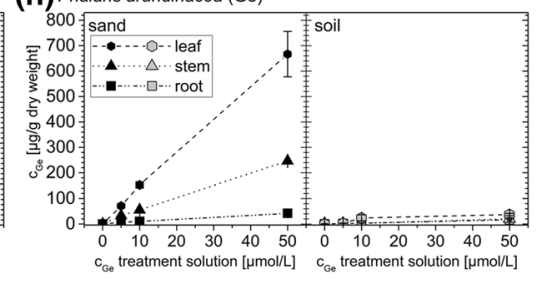

(i) Phalaris arundinacea (Ge/Si)

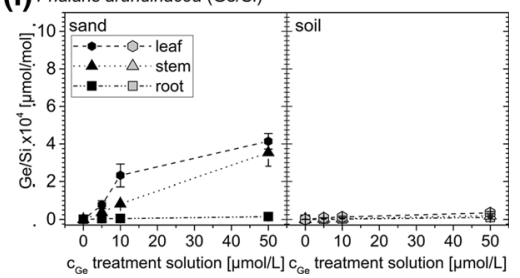

Fig. 1 Concentration of silicon $(\mathrm{Si})(\mathbf{a}, \mathbf{d}, \mathbf{g})$ and germanium $(\mathrm{Ge})(\mathbf{b}, \mathbf{e}, \mathbf{h})$ and $\mathrm{Ge} / \mathrm{Si}$ ratios $(\mathbf{c}, \mathbf{f}, \mathbf{i})$ in roots, stalks and leaves of three grass species which have grown on two different soils (sandy soil and typical soil) by adding germanium (germanium

as dependent on the substrates used showing significantly higher concentrations of $\mathrm{Ge}$ in sand-cultured plants compared to soil-grown plants. For example, on sand, Z. mays accumulated significantly higher concentrations of Ge in leaves (up to $411.97 \mu \mathrm{g} \mathrm{g}^{-1}$ ) and stems (up to $235.40 \mu \mathrm{g} \mathrm{g}^{-1}$ ) than on soil substrate (in stems up to $32.46 \mu \mathrm{g} \mathrm{g}^{-1}$; in leaves up to $\left.42.15 \mu \mathrm{g} \mathrm{g}^{-1}\right)$. The addition of our lowest Ge concentration of $5 \mu \mathrm{mol} \mathrm{L}{ }^{-1}$ resulted in higher $\mathrm{Ge}$ concentration in leaves of A. sativa $\left(76.89 \mu \mathrm{g} \mathrm{g}^{-1}\right)$ and $P$. arundinacea $\left(71.22 \mu \mathrm{g} \mathrm{g}^{-1}\right)$ on sand substrate than the addition of our highest Ge concentration in the treatment solution $\left(50 \mu \mathrm{mol} \mathrm{L}{ }^{-1}\right)$ in leaves of soil grown plants (A. sativa: $58.23 \mu \mathrm{g} \mathrm{g}^{-1}, P$. arundinacea: $37.14 \mu \mathrm{g} \mathrm{g}^{-1}$ ). The results for Ge concentration in dependency on the treatment are significant within a species at chosen substrate and within all species in all plant parts with a $\mathrm{p}$ value $<0.001$. This also applies to differences among the soil-grown species.

In contrast to $\mathrm{Si}, \mathrm{Ge}$ was found predominantly $(\approx 80 \%)$ in the above-ground biomass showing concentration of 5,10 or $50 \mu \mathrm{mol} \mathrm{L}{ }^{-1}$ in treatment solution). Each bar represents the mean of four replicates plus standard error $(n=4)$

decreasing concentrations in the order leaves $>$ stems $>$ roots. Due to addition of $50 \mu \mathrm{mol} \mathrm{L}{ }^{-1} \mathrm{Ge}$ in the treatment solution the concentrations of Ge led to maximum concentration of sand-grown plants (leaves: 411.97-666.75 $\mu \mathrm{g} \mathrm{g}^{-1}$, stems: $235.40-403.55 \mu \mathrm{g} \mathrm{g}^{-1}$; roots: 16.95$\left.59.29 \mu \mathrm{g} \mathrm{g}^{-1}\right)$. Also, the addition of Ge concentrations of 5 and $10 \mu \mathrm{mol} \mathrm{L}{ }^{-1}$ showed increased Ge concentrations in the plant tissue. Since Si concentrations in the growth media were not changed by the addition of $\mathrm{Ge}$, increasing the uptake of $\mathrm{Ge}$ in the plants also led to significantly increasing $\mathrm{Ge} / \mathrm{Si}$-ratios showing a maximum of $7.28 \times 10^{4} \pm 1.25 \times 10^{4}$ $\mu \mathrm{mol} \mathrm{mol}{ }^{-1}$ in Z. mays, $6.11 \times 10^{4} \pm 2.08 \times 10^{4}$ $\mu \mathrm{mol} \mathrm{mol}^{-1}$ in $A$. sativa and $4.14 \times 10^{4} \pm$ $4.16 \times 10^{3} \mu \mathrm{mol} \mathrm{mol}^{-1}$ in P. arundinacea (Fig. 1) at $50 \mu \mathrm{mol} \mathrm{L}{ }^{-1}$. Compared to the reference plants without Ge-treatment this represents an increase in the $\mathrm{Ge} / \mathrm{Si}$ ratios roughly by a factor up to 2300 for Z. mays and $P$. arundinacea (Fig. 1). Even an artificial Ge addition of $5 \mu \mathrm{mol} \mathrm{L}{ }^{-1}$ lead to an increase in the $\mathrm{Ge} / \mathrm{Si}$ ratio by a factor up to 200 in leaves of sand-cultured 
plants. It has to be noticed that due to species-specific differences in biomass production the total amount of $\mathrm{Ge}$ and Si taken up by the plants varied between the species. As a result, with regard to the treatment with $50 \mu \mathrm{mol} \mathrm{L}{ }^{-1} \mathrm{Ge}$, sand-cultured plants of $Z$. mays accumulated significantly higher amounts of $\mathrm{Ge}$ $(0.45 \mathrm{mg} \mathrm{Ge})$ in the above-ground biomass than plants of A. sativa (0.17 $\mathrm{mg} \mathrm{Ge})$.

Localization and chemical characterization of leaf phytoliths

Investigations by fluorescence microscopy and scanning electron microscopy (SEM) were performed to investigate the location of vascular bundles in leaf tissue and the shape and position of phytoliths. The vascular bundles of grasses run longitudinally and parallel to one another, they are connected by weaker transverse bundles (anastomoses). Phytoliths are arranged in parallel rows and situated along the leafveins, mostly at the main veins. In Zea mays the largest number of dumbbell and four-leaf clover-shaped phytoliths arranged along the veins, some along small veins and intercostal regions. The phytoliths of $\mathrm{Z}$. mays were well visible with SEM because they are
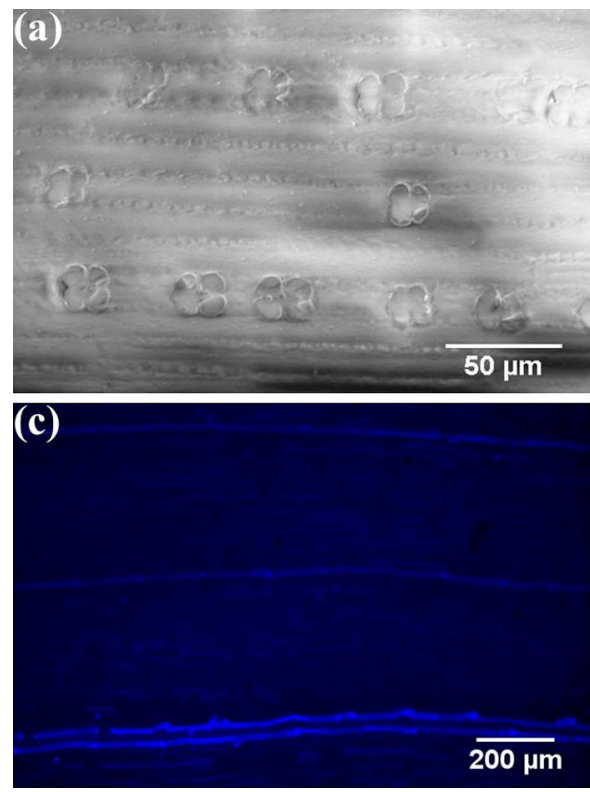

Fig. 2 Silica bodies in plant material (top view on leaf). a Scanning electron microscopy (SEM) picture of dumbbell and four-leaf clover-shaped phytoliths at the surface of a Zea mays leaf. b SEM picture of the Avena sativa leaf surface. Only barbshaped trichomes (double-breasted) are visible. c Fluorescent situated directly at the surface (Fig. 2a). In contrast, Avena sativa had long elongated silica bodies, but only the trichomes stand off the surface (Fig. 2b). To make the phytoliths visible, fluorescence microscopy was a suitable method (Fig. 2c, d). The phytoliths of $A$. sativa were partly arranged in a simple row or in pairs of two rows. The arrangement of phytoliths in $P$. arundinacea is not shown because they resemble A. sativa.

For detailed investigations on the structure and chemical composition of the phytoliths, the plant leaves of maize, oat and reed canary grass were burned in order to separate the phytoliths from surrounding organic cell structures and single phytoliths were analyzed by SEM and EDX (Fig. 3). The amount of ash was determined: Z. mays $8 \%$, A. sativa $15 \%$, $P$. arundinacea, $10 \%$, respectively. Unfortunately, as a result of the combustion process we observed that the oxidation of carbon cellular compounds was not completed and therefore the ash still contained some black residues, mostly around the vascular bundles of the leaf. An extension of the combustion time to $4 \mathrm{~h}$ did not cause any change.

Scanning electron microscopy (SEM) revealed that the washed ash residues consisted of plate-like silicas
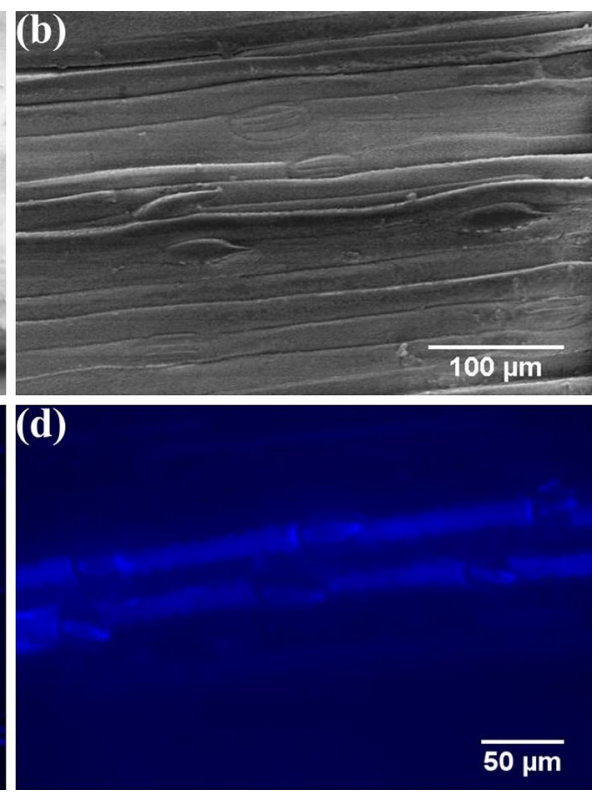

microscopic image: Parallel arrangement of phytoliths and trichomes in Avena sativa leaf $(\mathrm{NaOH}$ treatment for $10 \mathrm{~min}$, excitation time: $1 / 20 \mathrm{~s}$ ), d Fluorescent microscopic image: phytoliths and trichomes of picture (c) in detail $(\mathrm{NaOH}$ treatment for 10 min, excitation time: $1 / 9 \mathrm{~s}$ ) 

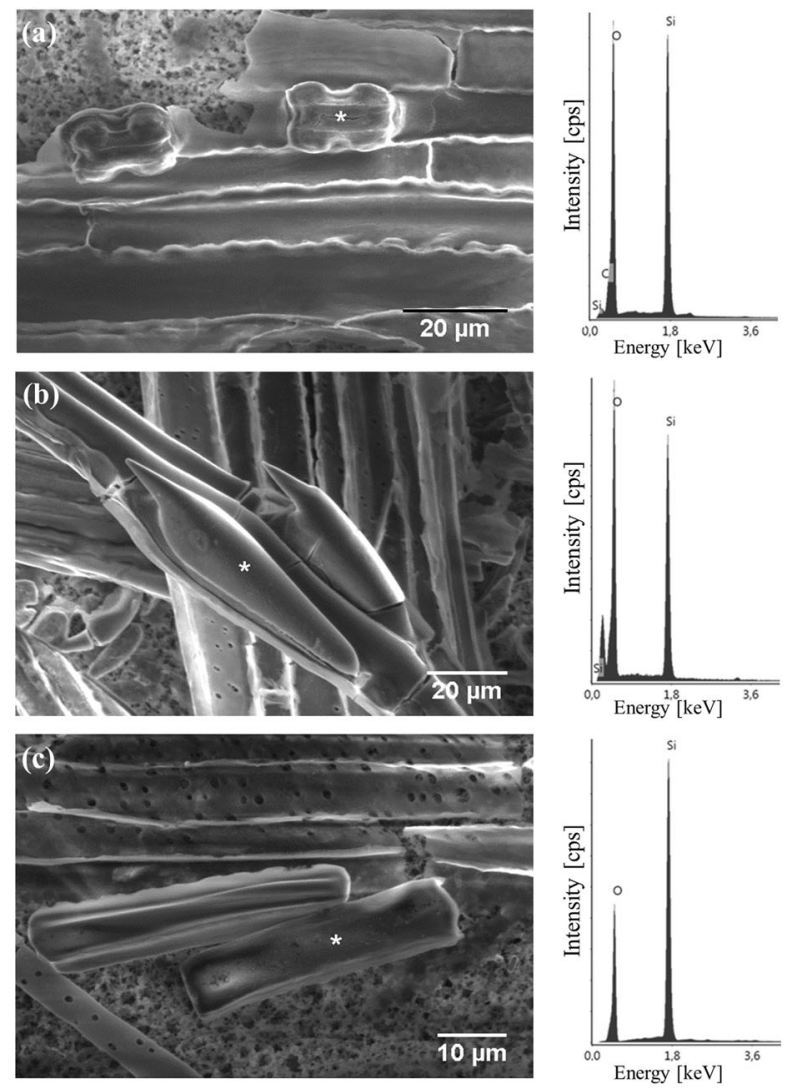

Fig. 3 Scanning electron microscopy (SEM) images of plant biosilica (ashed leaves, cleaned). The plants growing on sand substrate with a $\mathrm{Ge}$ concentration of $50 \mu \mathrm{mol} \mathrm{L}^{-1} \mathrm{Ge}$ in the treatment solution. Asterisks mark the position of performed energy dispersive X-ray spectroscopy (EDX) measurements. The EDX spectrum is shown on the right side of SEM image.

and species-specific phytoliths and trichomes (Fig. 3). Silica plates are normally located at the leaf surface, covered by organic material. SEM measurements demonstrated that the silica plate layer in Z. mays was around $300-400 \mathrm{~nm}$ thick (thickness measurement is not shown in the SEM) and directly connected to the dumbbell and four-leaf clover-shaped phytoliths with a size of 15-20 $\mu \mathrm{m}$ (Fig. 3a). The plates of maize were plugged into each other like a puzzle (Fig. 3b). In $A$. sativa the silica plate layer was around $360 \mathrm{~nm}$ thick. The rod-shaped phytoliths with a size of $100-110 \mu \mathrm{m}$ were not connected to the silica plates, only to barbshaped and angled silica trichomes (Fig. 3c). The silica layer of $P$. arundinacea was 290-300 nm thick. Similar to A. sativa, the rod-shape phytoliths (size around $40 \mu \mathrm{m}$ ) were not connected to the silica plates. We investigated all plant species at Ge treatment of
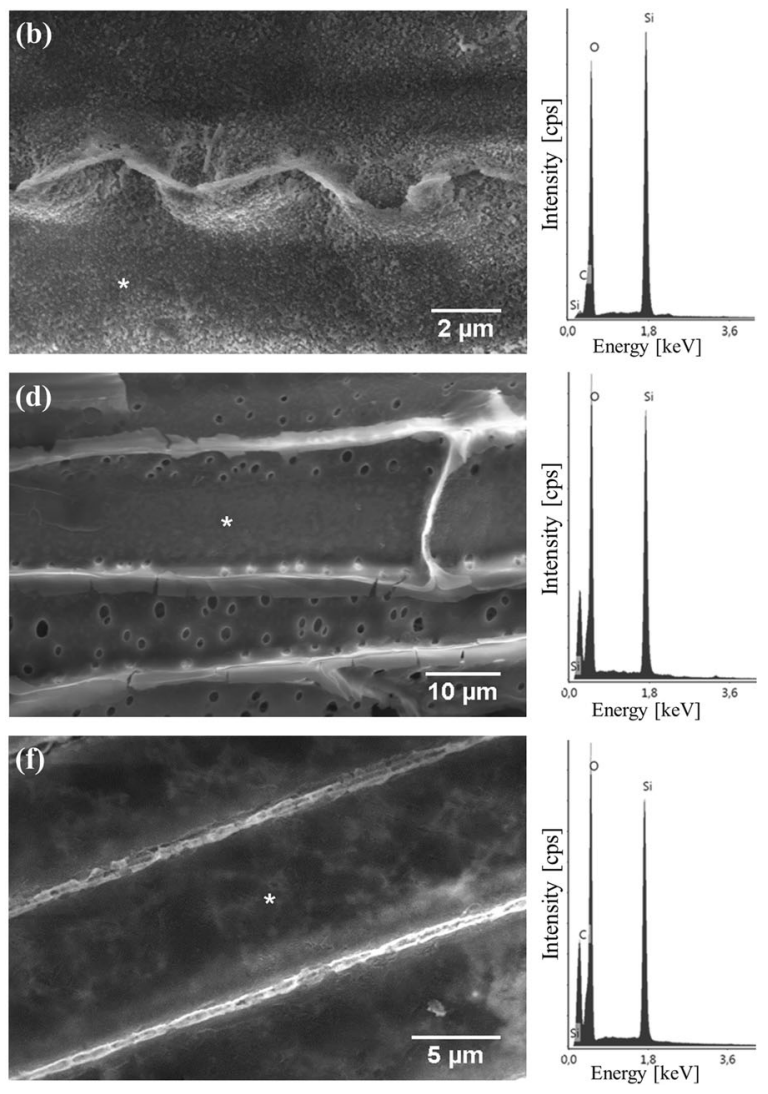

a Two dumbbell-shaped phytoliths of Zea mays embedded in silica plates. b Toothing of maize silica plates. c Phytoliths of Avena sativa with barb-shaped trichomes (in front). Silica plates are in the background. d Oat silica plates with connection. e Elongate phytoliths and silica plates of Phalaris arundinacea. f Connection of reed-canary grass silica plates

$50 \mu \mathrm{mol} \mathrm{L}{ }^{-1}$ and the reference plants and found no differences in the shapes and distribution of phytoliths. Figure 3 shows the representative results for plants with Ge treatment of $50 \mu \mathrm{mol} \mathrm{L}{ }^{-1}$. EDX measurements of the same samples confirmed that solid material consisted of $\mathrm{Si}$; however, we found no atomic $\mathrm{X}$-ray signal for Ge taking account an absolute detection limit of 1 atom\%.

Localization of Ge and Si within the plant leaves

LA-ICP-MS measurements were performed with leaves of Z. mays and A. sativa, including those plants growing on soil substrate without Ge addition (reference) as well as plants treated with $50 \mu \mathrm{mol}^{-1} \mathrm{Ge}$ on sand in order to measure the distribution of $\mathrm{Si}$ and $\mathrm{Ge}$ in the leaves. Plants of sand substrate were chosen due 
to higher Ge contents in the leaves (Fig. 1). The highest concentrations of $\mathrm{Si}$ were observed to run in parallel rows along the leaf axis with low Si signals between the rows (Fig. 4). Therefore, the high concentrations of $\mathrm{Si}$ coincide with the distribution of phytoliths within the leaves (see also Figs. 2, 3). In contrast to $\mathrm{Si}$, in both plants, the reference plants and plants treated with $50 \mu \mathrm{mol}{ }^{-1} \mathrm{Ge}$ solutions, respectively, Ge was detected in a markedly different pattern, particularly in reference plants with low Ge concentrations (Fig. 4, see also Table 2). Specifically, compared to $\mathrm{Si}, \mathrm{Ge}$ did not occur in parallel rows but was equally distributed over the whole leaf area without observable relation/coherency to/with $\mathrm{Si}$.
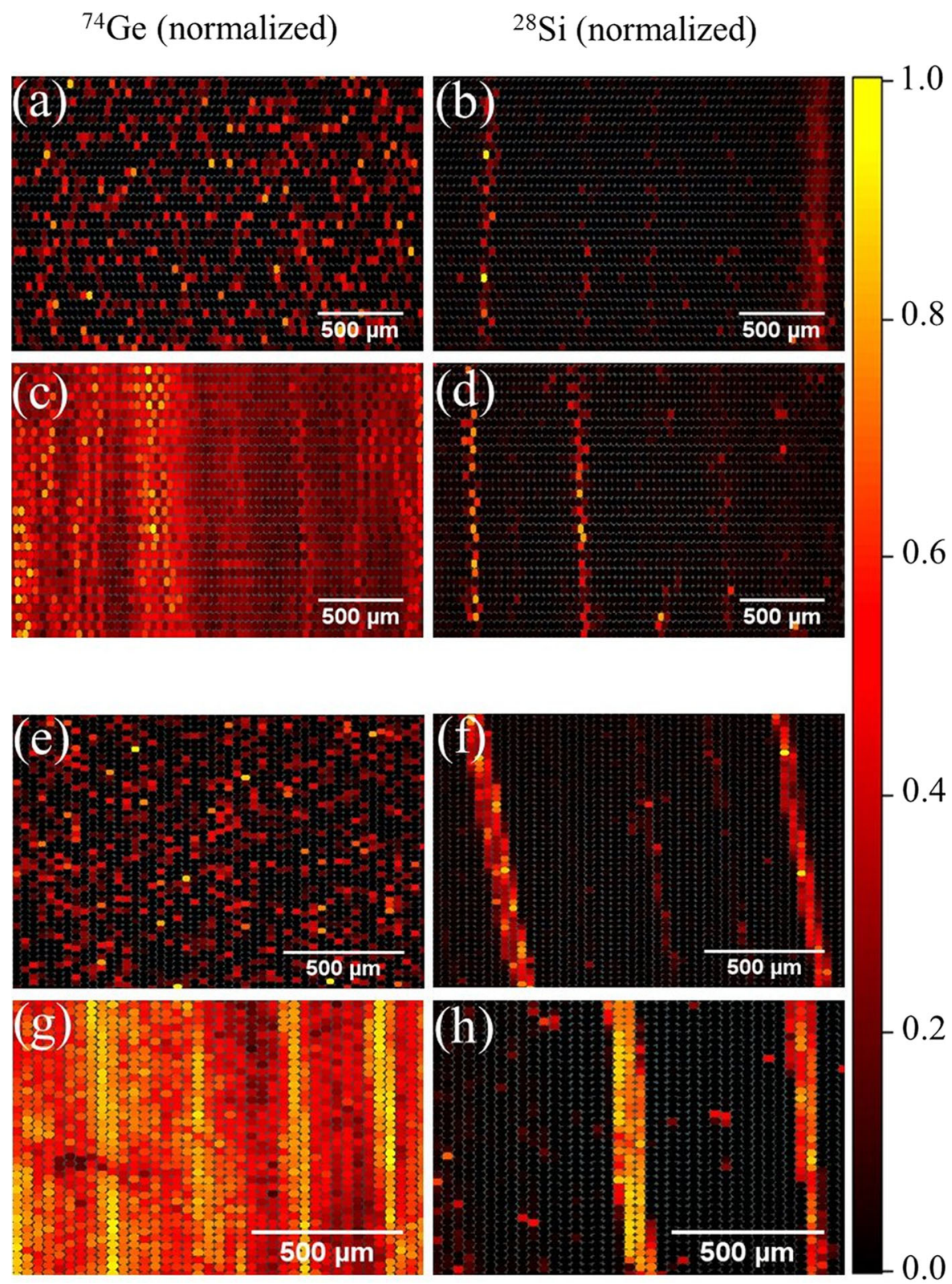

Fig. 4 2D-maps show the distribution of $\mathrm{Ge}$ and $\mathrm{Si}$ in leaves of Zea mays (a-d) and Avena sativa (c-h) by laser ablation inductively coupled plasma mass spectrometry (LA-ICP-MS) measurements. Relative intensity data of ${ }^{74} \mathrm{Ge}$ (left) and ${ }^{28} \mathrm{Si}$ (right) from same measured position are given. (a, b, e, f) reference plants without artificial $\mathrm{Ge}$ treatment. (c, d, d g, h) plants treated with $50 \mu \mathrm{mol} \mathrm{L}{ }^{-1} \mathrm{Ge}$ 
There were also no observable differences between the plant species, except for the size of the Si-containing stripes, most probably originating from the differences in the size and form of phytoliths (see also Fig. 2).

Application of $50 \mu \mathrm{mol} \mathrm{L}^{-1} \mathrm{Ge}$ to the sand cultured plants substantially changed the pattern of accumulation in the plants (Fig. 4). Besides of a large portion of Ge equally distributed over the leaves, in these samples highest concentrations of Ge occurred in parallel rows as it was observed for Si. However, we could clearly show that these Ge-containing stripes did not spatially overlap with the Si measured in the plants. Light microscopic observations clearly indicated that the Ge present in rows was located close to the vascular bundles and not in the phytoliths (data not shown here).

Distribution of $\mathrm{Ge}$ and $\mathrm{Si}$ in phytoliths and other organic tissue compounds

Figure 5 shows the amounts of $\mathrm{Si}$ and Ge present in organic (oxidizable) binding forms and biogenic silica. In reference plants $116.10 \pm 51.74 \mathrm{mg} \mathrm{g}^{-1} \mathrm{Si}$

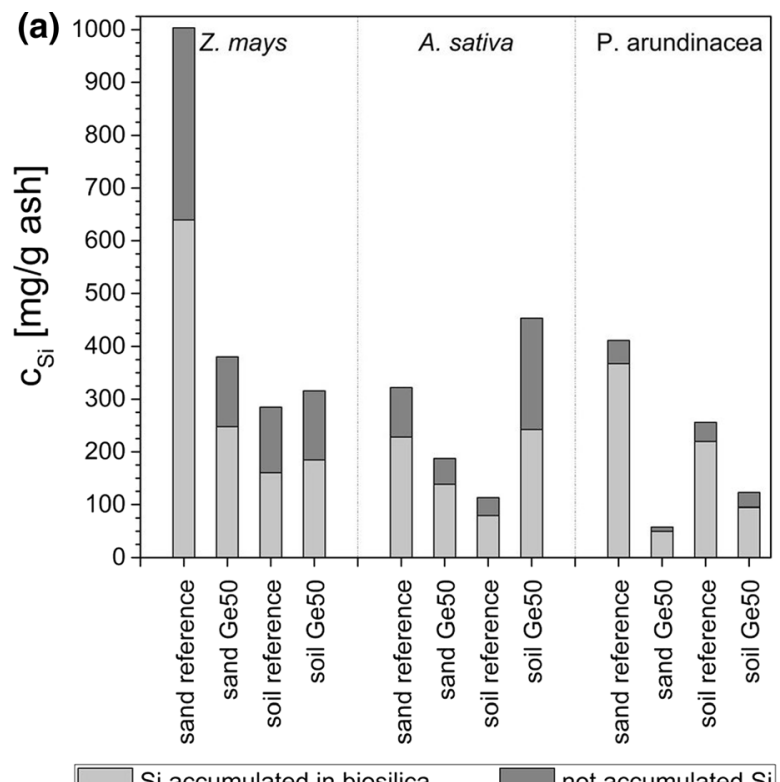

Fig. 5 Accumulated content of $\mathrm{Si}(\mathbf{a})$ and $\mathrm{Ge}(\mathbf{b})$ in biosilica of (ashed) grass leaves (maize, oat, reed-canary grass). Data of reference plants without artificial Ge treatment and plants treated with $50 \mu \mathrm{mol} \mathrm{L}{ }^{-1} \mathrm{Ge}$ are shown as well as the soil type. and $11.61 \pm 4.21 \mu \mathrm{g} \mathrm{g}^{-1}$ Ge were determined in the dissolved ash/liquid phase, while $282.43 \pm$ $81.18 \mathrm{mg} \mathrm{g}^{-1} \mathrm{Si}$ and $2.67 \pm 2.08 \mu \mathrm{g} \mathrm{g}^{-1} \mathrm{Ge}$ were present in the biosilica. Addition of Ge $\left(50 \mu \mathrm{mol} \mathrm{L}{ }^{-1}\right)$ increased the total amounts of $\mathrm{Ge}$ in the samples but the distribution of $\mathrm{Ge}$ between biosilica and the organic material remained nearly constant: $93.36 \pm$ $31.85 \mathrm{mg} \mathrm{g}^{-1} \mathrm{Si}$ and $13,457.44 \pm 5109.78 \mu \mathrm{g} \mathrm{g}^{-1}$ Ge were determined in the dissolved ash/liquid phase, while $159.70 \pm 32.62 \mathrm{mg} \mathrm{g}^{-1} \mathrm{Si}$ and $660.38 \pm$ $393.00 \mu \mathrm{g} \mathrm{g}^{-1} \mathrm{Ge}$ were present in the biosilica. In reference plants $72.7 \pm 5.2 \%$ of the present Si concentration was fixed as biosilica, while only $14.4 \pm 4.5 \%$ of $\mathrm{Ge}$ were embedded in biosilica. In $50 \mu \mathrm{mol} \mathrm{L}{ }^{-1} \mathrm{Ge}$ treated plants the value was $69.0 \pm 5.0 \%$ of the present $\mathrm{Si}$ and $3.9 \pm 1.1 \%$ of $\mathrm{Ge}$ (Fig. 5).

Nevertheless, addition of $\mathrm{Ge}$ to the treatment solution led to high $\mathrm{Ge} / \mathrm{Si}$ ratios (94.59$\left.9136.04 \mu \mathrm{mol} \mathrm{mol}{ }^{-1}\right)$ in phytoliths due to the addition of germanium (Online Resource 2). In contrast, the phytoliths of reference plants of Z. mays, A. sativa and $P$. arundinacea show $\mathrm{Ge} / \mathrm{Si}$ ratios in phytoliths in the

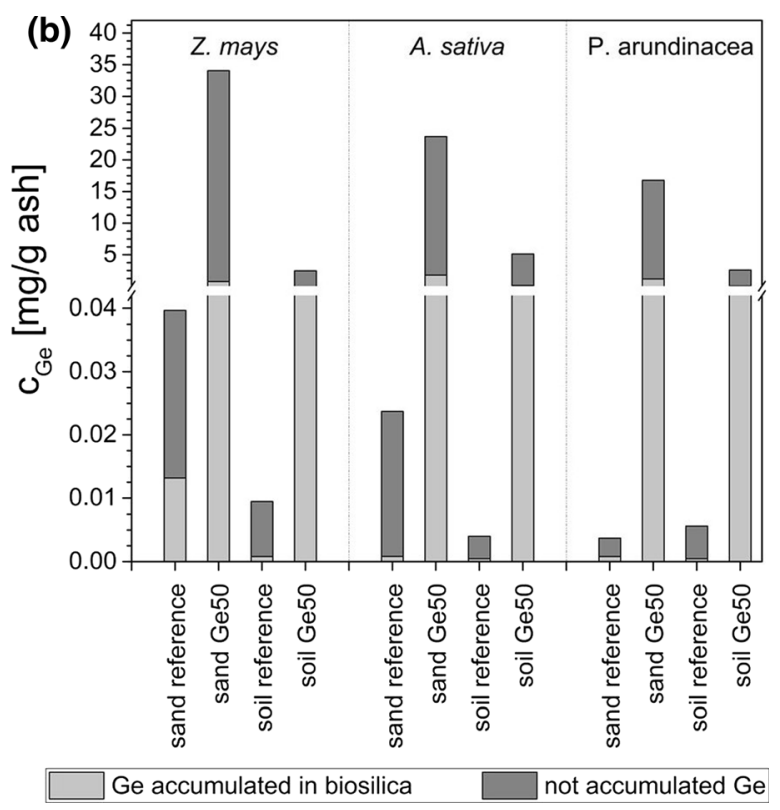

Note the logarithmic scale of (b). In contrast to silicon, which is predominantly incorporated in biogenic opal, only a small amount of germanium is accumulated in the amorphous phase 
range of $0.83-7.96 \mu \mathrm{mol} \mathrm{mol}{ }^{-1}$. However, the values are not comparable because of different environmental conditions and other plant species.

\section{Discussion}

Uptake and accumulation of $\mathrm{Ge} / \mathrm{Si}$ in different plant tissues of the three investigated grass species

As for every other element uptake and accumulation of Ge and Si from soil in plants depends on its availability in soils influenced by the mobility and chemical speciation in the rhizosphere as well as physiological traits targeting a chemical form for uptake und translocation. Additionally, to a passive movement of elements through diffusion and mass-flow occurring in all plants, in species from the functional group of grasses several aquaporin-type transporters have been described (Tensho and Yeh 1972; Ma 2003; Mitani et al. 2005, 2009; Ma et al. 2007; Yamaji et al. 2008; Tamai and Ma 2003; Yamaji and Ma 2009, 2011; Pontigo et al. 2015) mediating active uptake and translocation of $\mathrm{Ge}$ and $\mathrm{Si}$ from soil solution. As a consequence, grasses are often considered as accumulators of $\mathrm{Si}$ and $\mathrm{Ge}$ (Wiche et al. 2018), which is in good agreement to the outcome of the present study, where reference plants on soil (without $\mathrm{Ge}$ addition) were characterized by $\mathrm{Ge}$ and $\mathrm{Si}$ with concentrations a factor of 10-100 higher compared to non-Si-accumulator species described in the literature (Wiche et al.2018). The treatment of plants with $\mathrm{Ge}$ in form of $\mathrm{Ge}(\mathrm{OH})_{4}$ led to a nearly linear increase of the Ge concentrations (Fig. 1) in all species and on both substrates sand and soil, respectively, showing increasing concentrations in plant tissues in the order roots $<$ stems $<$ leaves (Fig. 1). The linearity observed on both substrates indicates a non-saturable uptake kinetics and preferred translocation and sequestration of $\mathrm{Ge}$ in the shoots. Concomitantly with increasing Ge concentrations we observed decreasing concentrations of $\mathrm{Si}$ in roots of soil and sand grown plants, indicating a competition of $\mathrm{Ge}$ and Si during uptake as already described by Rains et al. (2006) and Nikolic et al. (2006). It has to be noticed that this pattern was only observable in the roots without effects in the leaves and stems, suggesting that the competition predominantly takes place during the uptake in root cortex cells rather than during xylem loading and root-shoot transfer. Moreover, it is reasonable that the Ge supplied to the plants influenced the formation of the casparian band through formation of complexes with phenolic compounds (Fleck et al. 2015).

In all investigated plant species and both substrates total amounts of elements taken up by the plants (calculated as product of concentration and biomass) strongly corresponded to plant growth and biomass formation with accumulated amounts of $\mathrm{Ge}$ and $\mathrm{Si}$ decreasing in the order Z. mays, $P$. arundinacea $>A$. sativa (Online Resource 1). The shoots of soil-grown reference plants (in contrast to plants cultivated on sand) accumulated $1.13 \mu \mathrm{g}$ Ge and $6.45 \mathrm{mg} \mathrm{Si}(Z$. mays), $0.45 \mu \mathrm{g} \mathrm{Ge}$ and $4.6 \mathrm{mg} \mathrm{Si} \mathrm{(P.} \mathrm{arundinacea)} \mathrm{and}$ $0.07 \mu \mathrm{g} \mathrm{Ge}$ and $0.83 \mathrm{mg} \mathrm{Si}$ (A. sativa). As a comparison amounts of elements sequestrated in belowground plant parts (roots) were $0.53 \mu \mathrm{g} \mathrm{Ge}$ and $8.66 \mathrm{mg} \mathrm{Si}$ in Z. mays, $0.77 \mu \mathrm{g} \mathrm{Ge}$ and $17.77 \mathrm{mg} \mathrm{Si}$ in $P$. arundinacea and $0.07 \mu \mathrm{g} \mathrm{Ge}$ and $2.64 \mathrm{mg} \mathrm{Si}$ in A. sativa, respectively. Surely, root concentrations are often strongly biased by adhering soil particles; however, these results highlight the species-specific differences in elemental accumulation among the investigated species, particularly in aboveground plant parts.

In sand cultures the experimental design allowed to calculate the percentage of Ge taken up by the plants from the watering solutions which was $10.7 \pm 0.9 \%$ (Z. mays), $14.7 \pm 1.9 \%$ (P. arundinacea) and $4.2 \pm 0.5 \%$ (A. sativa), irrespective of the concentrations of the treatment solution. This suggests that $P$. arundinacea and $Z$. mays seem to deploy more efficient uptake mechanisms of Ge than A. sativa per unit biomass. However, the impact of other belowground functional and structural traits involved in $\mathrm{Si}$ nutrition such as release of root exudates and root architecture cannot a priori be ruled out. Indeed, in our experiment $A$. sativa was characterized by a significantly lower root biomass compared to $Z$. mays (Online Resource 1) so that a lower element uptake could simply derive from a lower root surface area of the A. sativa cultivar. Surprisingly, in reference pots filled with sand without addition of Ge the plants showed similar pattern of accumulated amounts of elements among the different species. This suggests that all species were able to access sparingly soluble Ge-bearing mineral phases such as Fe-oxyhydroxides and secondary clays which were present as impurities of the sand (Table 2). A comparison of plants 
cultivated on soil with those on sand revealed significantly lower concentrations in soil than on sand, except in the reference plants where Ge was not artificially added (Fig. 1, Online Resource 1). This can be largely explained by interactions of the Ge in the watering solution with Fe-oxyhydroxides and soil organic matter lowering its solubility and therefore availability to plants (Bernstein 1985; Kabata-Pendias 2010; Wiche et al. 2018).

Overall these results suggest that the mobilization of $\mathrm{Ge}$ together with $\mathrm{Si}$ in the rhizosphere is a common mechanism among grasses to maintain $\mathrm{Si}$ supply.However, differences in the capability to take up the mobilized elements and transfer it into the shoots seems to be the critical step determining the distribution/allocation/accumulation of Ge in different plant tissues. In sand cultures with high Ge supply we found highest concentrations in above-ground plant parts, particularly the leaves of A. sativa $\left(599.2 \mu \mathrm{g} \mathrm{g}^{-1}\right)$ and $P$. arundinacea $\left(666.7 \mu \mathrm{g} \mathrm{g}^{-1}\right)$ that were roughly a factor of 1.5 higher compared to $Z$. mays $\left(412.0 \mu \mathrm{g} \mathrm{g}^{-1}\right)$. In contrast, when Ge availability was low which was the case in soil reference plants, the pattern substantially changed showing highest concentrations in stems ( $P$. arundinacea), in roots $(A$. sativa) or even similar concentrations in all plant parts (Z. mays) (Table 3). This result suggests a concentration dependent distribution of Ge along the shoot axis due to interactions of Ge with various cell structures. The rationale behind this contention is that compared to $\mathrm{Si}, \mathrm{Ge}$ shows a higher reactivity in terms to forms stable complexes with many functional groups (Pokrovski and Schott 1998) and therefore may interact with cell constituents such as cell walls and ligands in the cytosol. Therefore these patterns may depend on a saturation of potential binding sites needed before the element can be further transported along the shoot axis with the transpiration stream (Choi et al. 2013). This is supported by our findings that root concentrations were similar in all experiments and plant species, while concentrations in above-ground plant parts varied greatly among species and the Ge concentrations supplied (Fig. 1; Table 3). However, since we did not expect these effects, based on our experimental design our data allows no further interpretation and following experiments on effects of root exudates, microbial interactions in the rhizosphere as well as chemical forms of $\mathrm{Ge}$ and $\mathrm{Si}$ within the plant are needed.
Chemical binding forms of $\mathrm{Ge} / \mathrm{Si}$ in grass plant tissues

Until recently it has been generally assumed that $\mathrm{Ge}$ taken up by plants is transported together with Si to sites where transpiration takes place and where it is stored in phytoliths together with Si (plant opal/ biosilica) (Blecker et al. 2007). In fact, the process of biosilica formation in plants is not yet fully understood and there still is a debate on whether uncontrolled changes in solution equilibria at sites of transpiration are responsible for the polymerization/condensation of monomeric $\mathrm{H}_{4} \mathrm{SiO}_{4}$ or biosilica formation is cellular controlled by involving specific biomolecules such as proteins, peptides and polysaccharides. Recently Soukup et al. (2017) demonstrated the formation of root phytoliths in Sorghum bicolor which favours the hypothesis involving cell control instead of an uncontrolled spontaneous reaction. In above ground plant parts, leaves and stems, respectively phytoliths formation may take place in cell walls or cell lumina (Hodson 2016). Cell wall phytoliths develop through silica deposits on carbohydrates such as hemicellulose, cellulose, arabinoxylan or callose while phytoliths in the cell lumen emerge not in membranebound vesicles, instead, they are filled in by silica granules in the lumen (Hodson 2016). The chemical composition of phytoliths may vary greatly in dependence on the processes during formation, plant age and environmental conditions affecting plant mineral composition and plant growth (Hodson 2016). However, there is general consensus that biosilica basically consists of organic and inorganic constituents (Hodson 2016), predominantly $\mathrm{Si}(\mathrm{OSi})_{3}(\mathrm{OH})$ and $\mathrm{Si}(\mathrm{OSi})_{4}$ (Mann et al. 1983). Besides biosilica may contain also a number of other elements including $\mathrm{Ge}, \mathrm{Ca}, \mathrm{Al}$, C (Hodson 2016). However, to our best knowledge there is no report available in the literature elucidating the amounts of Ge contained in phytoliths in dependence of the bulk Ge-contents of plants. In the present study for both investigated plant species (A. sativa and Z. mays) biosilicification was observed through microscopy investigations. Reference plants as well as plants treated with Ge showed phytoliths and silica plates in their leaves as previously described in the literature (Twiss et al. 1969; Cheng et al. 2003; Ma 2003; Zhang et al. 2011; Andrade et al. 2014). Analysis of the elemental composition of the phytoliths by EDX revealed a strong signal for Si but no 
signal for $\mathrm{Ge}$ in both reference plants and plants treated with high doses of Ge. It has to be noticed that the detection limits of this method may be not sufficient to quantify Ge in phytoliths. However, laser ablation ICP-MS (LA-ICP-MS) clearly showed that $\mathrm{Si}$ was present in parallel rows along the leaf-axis and along the previously identified phytoliths, while Ge appeared unequally distributed in the leaf mesophyll and bundle tissues. Finally, we extracted the phytoliths from the leaves by dry ashing method for phytolith extraction that is commonly used in biogeochemical research. As a result, we found that relative to the amounts of $\mathrm{Ge}$ and Si taken up by the plants only a minor fraction was present in the inorganic phytolith fraction. For maize plant treated with a total of $60 \mu \mathrm{mol} \mathrm{L}{ }^{-1}$ Ge only $1.8-2.2 \%$ of total leaf Ge was present in phytoliths. In contrast, the extracted phytoliths contained $58.5-65.1 \% \mathrm{Si}$ in the plants proving that silicification is responsible for the sequestration of $\mathrm{Si}$ in plant biomass, while Ge was mostly present in the oxidizable organic phase (Table 4, Fig. 5, Online Resource 2). Indeed, Delvigne et al. (2009) and Opfergelt et al. (2010) previously demonstrated a discrimination of $\mathrm{Ge}$ and heavy $\mathrm{Si}$ isotopes compared to the more abundant light $\mathrm{Si}$ during uptake and accumulation in plants which may in turn impact the distribution of elements among different plant tissues and the composition of phytoliths. Moreover, unlike $\mathrm{Si}, \mathrm{Ge}$ shows distinct siderophilic and organophilic behavior in the environment, mostly due to its ability to increase the coordination to six and thus higher reactivity with many functional groups present in plant tissues. In plant cells myriads of possible binding sites are present including cell wall components, membrane-bound and free cytosolic proteins, carboxylates, phenolic compounds and sugars, which may interact with Ge. Very recently Wang et al. (2018) showed that Ge taken up by apple leaves is rapidly transferred into Ge-organic species. Previously, Matsumoto et al. (1975) and Matsumoto and Takahashi (1976) identified organic binding forms of $\mathrm{Ge}$ in rice plants, most probably $\mathrm{Ge}$ associated to proteins. Possibly after being taken up and transported to the shoots, Ge in grasses also interacts with organic cellular compounds, thus leading to a discrimination of Ge relative to Si during the transport to sites where silicification takes place. This could explain the disorderly distribution within the leaf tissues and low Ge/Si ratios in phytoliths compared to the amounts of Ge and Si taken up by plants.

Surely, the mineral composition of phytoliths may vary in dependence on mineral composition of plants and plant age (Kumar et al. 2017a, b). Therefore, we cannot strictly rule out the possibility that some phytoliths are formed shortly before shoot senescence which may differ in their Ge/Si-ratios from those in mature plants. We emphasize that in soil grown reference plants the percentage of $\mathrm{Ge}$ present in phytoliths of the flowering plants of A. sativa was similar to those of $Z$. mays and P. arundinacea in vegetative phase (Table 4, Online Resource 2). However, the processes involved remain unclear and further research on chemical binding forms of $\mathrm{Ge}$ within plant tissues, substrate specificity of transporters as well as the silicification process during plant development are needed.

Table 4 Germanium concentration in the amorphous part of the ashed leaves (reference plants without artificial Ge treatment) as well as percentage of the total Ge amount in the leaf

\begin{tabular}{llccc}
\hline \multirow{2}{*}{ Species } & Soil type & \multicolumn{2}{c}{ Ge in the amorphous phase of leaf ash (phytoliths) } & Ge/Si ratio in phytoliths $\left(\mu \mathrm{mol} \mathrm{mol}^{-1}\right)$ \\
\cline { 2 - 4 } & & $\mu \mathrm{g} \mathrm{g}^{-1}$ & $\%$ & 7.96 \\
\hline \multirow{2}{*}{ Z. mays } & Sand & 13.2 & 33.2 & 1.95 \\
& Soil & 0.8 & 8.6 & 1.41 \\
\multirow{3}{*}{ P. arundinacea } & Sand & 0.8 & 3.5 & 2.24 \\
& Soil & 0.5 & 11.5 & 0.84 \\
& Sand & 0.8 & 21.5 & 0.83 \\
\hline
\end{tabular}


Implications on the biogeochemical cycling of $\mathrm{Ge}$ and $\mathrm{Si}$

Grasses have an indisputably important role in the biogeochemical cycling of both, silicon ( $\mathrm{Si}$ ) and germanium $(\mathrm{Ge})$, since these species widely occur in many ecosystems and are able to accumulate high amounts of the elements in their above- and belowground biomass (Street-Perrott and Barker 2008; Trembath-Reichert et al. 2015), highlighting a strong imprint of plants on the cycling of these elements. The uptake of both elements from soils depends on their availability in soil controlled by the mobility and chemical speciation in soil solution. Although rather little studied, species-specific rhizosphere processes may strongly affect the efficiency of plants to access elements from different mineral and organic soil phases (Wiche and Heilmeier 2016). Subsequently, during uptake and translocation a discrimination of $\mathrm{Ge}$ relative to Si occurs leading to very low $\mathrm{Ge} / \mathrm{Si}$ ratios in leaf-phytoliths $\quad\left(0.83-1.19 \mu \mathrm{mol} \mathrm{mol}{ }^{-1}\right.$, reference plants on soil substrate). These values are in good agreement with the findings of Blecker et al. (2007) and Derry et al. (2007) who found Ge/Si ratios between 0.04 and $0.37 \mu \mathrm{mol} \mathrm{mol}{ }^{-1}$ in phytoliths of various grasses cultivated on soil with low availability of $\mathrm{Ge}$. Compared to the $\mathrm{Ge} / \mathrm{Si}$ in phytoliths, bulk Ge/Si in biomass of the leaves of soil grown reference plants was $10-38 \mu \mathrm{mol} \mathrm{mol}^{-1}$ and reached up to $200 \mu \mathrm{mol} \mathrm{mol}^{-1}$ in stems, reflecting the initial Ge/Si ratios in potentially available soil fractions (Table 2).

However, evidence available from our results indicates that during soil-plant transfer only a minor fraction of the Ge taken up by plants is stored in phytoliths, whereas the major part $(67-98 \%$ Ge; Table 4 and Online Resource 2) seems to be retained in organic fractions. In contrast, most of the $\mathrm{Si}(71 \%)$ taken up by grasses is sequestrated in phytoliths (Fig. 5). During plant senescense, the elements are transferred back to soil through litterfall and are released from the litter through microbial decomposition (Sommer et al. 2006). Since other mineral soil phases and phytoliths are much more stable than organic material it seems reasonable that the organicbound Ge pool in soils has a strong imprint on the cycling of Ge. Particularly in well aerated surface soil layers phytoliths accumulate over time and form important biogenic Si and Ge pools (Cornelis et al.
2010; White et al. 2012) characterized by low Ge/Si ratios.

This may also explain the differences between $\mathrm{Si}$ and Ge in shallow soil solution, forest floor leachates and organic enriched soil horizons reported by Cornelis et al. (2010) and White et al. (2012) where Ge/Si ratios were much higher $\left(0.8-3.7 \mu \mathrm{mol} \mathrm{mol}{ }^{-1}\right)$ compared to phytolith and plant parts. Surely, in our experiment, we did not focus on element pathways and the results obtained cannot be directly extrapolated to field conditions. However, we could clearly demonstrate that $\mathrm{Ge} / \mathrm{Si}$ ratios in plant phytoliths do not quantitatively reflect element uptake and therefore in biogeochemical research soil organics, the elements bound herein and interactions between organic phases as well primary and secondary mineral phases should be considered.

\section{Conclusions}

Plants from the functional group of grasses accumulate high amounts of $\mathrm{Si}$ and $\mathrm{Ge}$ in their biomass. Based on the chemical similarities between $\mathrm{Ge}$ and $\mathrm{Si}$ for a long time it was assumed that Ge taken up by plants behaves similarly in the plant and is stored in phytoliths together with $\mathrm{Si}$ justifying the use of phytolith $\mathrm{Ge} / \mathrm{Si}$ ratios to trace biogeochemical cycling of Si. However, as a major outcome of our study we could demonstrate that the major portion of Ge taken up by grasses is not sequestrated in phytoliths and this was the case under natural growth conditions as well as under strongly elevated levels of $\mathrm{Ge}$ in the cultivation substrate. This highlights the role of soil organic matter on biogeochemical cycling of Ge and strongly suggests that the use of Ge/Si in phytoliths is not adequate to evaluate the uptake of Ge in plants. Thus, in field experiments bulk Ge/Si of plant biomass as well as in phytoliths must be taken into account to evaluate the significance of this parameter as tracer of biogeochemical cycling of $\mathrm{Si}$.

Acknowledgements This work was partially supported by BHMZ Programme of Dr.-Erich-Krüger-Foundation (Germany) at TU Bergakademie Freiberg. The authors appreciate the support of ProVIS Center for Chemical Microscopy by the Helmholtz Centre for Environmental Research - UFZ and the funds for ProVIS establishment provided by EFRE (Europäischer Fonds für regionale Entwicklung) and the federal state (Freistaat Sachsen). Authors are thankful to 
Hermann Heilmeier for discussions and many valuable comments on the manuscript. The authors would also like to thank Uta Fischer (SEM) and Uwe Sczech (freeze drying) for technical support. Open access funding provided by Projekt DEAL.

Open Access This article is licensed under a Creative Commons Attribution 4.0 International License, which permits use, sharing, adaptation, distribution and reproduction in any medium or format, as long as you give appropriate credit to the original author(s) and the source, provide a link to the Creative Commons licence, and indicate if changes were made. The images or other third party material in this article are included in the article's Creative Commons licence, unless indicated otherwise in a credit line to the material. If material is not included in the article's Creative Commons licence and your intended use is not permitted by statutory regulation or exceeds the permitted use, you will need to obtain permission directly from the copyright holder. To view a copy of this licence, visit http://creativecommons.org/licenses/by/4.0/.

\section{References}

Andrade FA, Andrade Júnior O, Andrade CGTJ, Miglioranza E (2014) Accumulation of silicon and arrangement and shapes of silica bodies in corn leaves. Genet Mol Res (GMR) 13(1):1690-1696. https://doi.org/10.4238/2014. January.24.6

Bakhat HF, Bibi N, Zia Z, Abbas S, Hammad HM, Fahad S, Ashraf MR, Shah GM, Rabbani F, Saeed S (2018) Silicon mitigates biotic stresses in crop plants: a review. Crop Prot 104:21-34. https://doi.org/10.1016/j.cropro.2017.10.008

Balakhnina T, Borkowska A (2013) Effects of silicon on plant resistance to environmental stresses. Rev Int Agrophys 27(2):225-232. https://doi.org/10.2478/v10247012-0089-4

Bernstein LR (1985) Germanium geochemistry and mineralogy. Geochim Cosmochim Acta 49(11):2409-2422. https://doi. org/10.1016/0016-7037(85)90241-8

Blecker SW, King SL, Derry LA, Chadwick OA, Ippolito JA, Kelly EF (2007) The ratio of germanium to silicon in plant phytoliths: quantification of biological discrimination under controlled experimental conditions. Biogeochemistry 86(2):189-199. https://doi.org/10.1007/s10533-0079154-7

Bolleter WT, Bushman CJ, Tidwell PW (1961) Spectrophotometric Determination of Ammonia as Indophenol. Anal Chem 33(4):592-594

Cheng P-C, Sun C-K, Cheng WY, Walden DB (2003) Nonlinear bio-photonic crystal effect of silica deposition in plants. Microsc Microanal 9(2):1354-1355

Choi IW, Seo DC, Han MJ, DeLaune RD, Ok YS, Jeon WT, Lim BJ, Cheong YH, Kang HW, Cho JS (2013) Accumulation and toxicity of germanium in cucumber under different types of germaniums. Commun Soil Sci Plant Anal 44(20):3006-3019. https://doi.org/10.1080/00103624. 2013.829083

Cornelis J-T, Delvaux B, Cardinal D, André L, Ranger J, Opfergelt S (2010) Tracing mechanisms controlling the release of dissolved silicon in forest soil solutions using $\mathrm{Si}$ isotopes and $\mathrm{Ge} / \mathrm{Si}$ ratios. Geochim Cosmochim Acta 74(14):3913-3924. https://doi.org/10.1016/j.gca.2010.04. 056

Delvigne C, Opfergelt S, Cardinal D, Delvaux B, André L (2009) Distinct silicon and germanium pathways in the soil-plant system: Evidence from banana and horsetail. J Geophys Res 114(G2):G02013. https://doi.org/10.1029/ 2008JG000899

Derry LA, Kurtz AC, Ziegler K, Chadwick OA (2005) Biological control of terrestrial silica cycling and export fluxes to watersheds. Nature 433(7027):728-731. https://doi.org/ 10.1038/nature03299

Epstein E (1999) Silicon. Annu Rev Plant Physiol Plant Mol Biol 50:641-664. https://doi.org/10.1146/annurev.arplant. 50.1.641

Etesami H, Jeong BR (2018) Silicon (Si): review and future prospects on the action mechanisms in alleviating biotic and abiotic stresses in plants. Ecotoxicol Environ Saf 147:881-896. https://doi.org/10.1016/j.ecoenv.2017.09. 063

Fleck AT, Schulze S, Hinrichs M, Specht A, Wassmann F, Schreiber L, Schenk MK (2015) Silicon promotes exodermal casparian band formation in Si-accumulating and Si-excluding species by forming phenol complexes. PLoS ONE 10(9):e0138555. https://doi.org/10.1371/journal. pone. 0138555

Froelich PN, Hambrick GA, Andreae MO, Mortlock RA, Edmond JM (1985) The geochemistry of inorganic germanium in natural waters. $J$ Geophys Res 90(C1):1133-1141. https://doi.org/10.1029/ JC090iC01p01133

Garvin CJ (2006) An exploratory study of the terrestrial biogeochemical silicon cycle at a forested watershed in Northern Vermont. Master Thesis, Cornell University

Goldschmidt VM (1926) Über das krystallochemische und geochemische Verhalten des Germaniums. Die Naturwissenschaften 14(14):295-297

Hartley AM, Asai RI (1963) Spectrophotometric determination of nitrate with 2,6-Xylenol reagent. Anal Chem 35(9):1207-1213

Hodson MJ (2016) The development of phytoliths in plants and its influence on their chemistry and isotopic composition. Implications for palaeoecology and archaeology. J Archaeol Sci 68:62-69. https://doi.org/10.1016/j.jas.2015.09. 002

Hodson MJ, White PJ, Mead A, Broadley MR (2005) Phylogenetic variation in the silicon composition of plants. Ann Bot 96(6):1027-1046. https://doi.org/10.1093/aob/mci255

Höll R, Kling M, Schroll E (2007) Metallogenesis of germanium—a review. Ore Geol Rev 30(3-4):145-180. https:// doi.org/10.1016/j.oregeorev.2005.07.034

Jeffryes C, Solanki R, Rangineni Y, Wang W, Chang C, Rorrer GL (2008) Electroluminescence and photoluminescence from nanostructured diatom frustules containing metabolically inserted germanium. Adv Mater 20(13):2633-2637

Kabata-Pendias A (2010) Trace elements in soils and plants, 4th edn. CRC Press/Taylor \& Francis Group, Boca Raton

Katz O (2019) Silicon content is a plant functional trait. Implications in a changing world. Flora 254:88-94. https:// doi.org/10.1016/j.flora.2018.08.007 
Kumar S, Milstein Y, Brami Y, Elbaum M, Elbaum R (2017a) Mechanism of silica deposition in sorghum silica cells. New Phytol 213(2):791-798. https://doi.org/10.1111/nph. 14173

Kumar S, Soukup M, Elbaum R (2017b) Silicification in grasses: variation between different cell types. Front Plant Sci 8:438. https://doi.org/10.3389/fpls.2017.00438

Kumar S, Adiram-Filiba N, Blum S, Sanchez-Lopez JA, Tzfadia O, Omis A, Volpin H, Heifetz Y, Goobes G, Elbaum R (2019) Siliplant1 (Slp1) protein precipitates silica in sorghum silica cells. bioRxiv. https://doi.org/10.1101/518332

Kurtz AC, Derry LA, Chadwick OA (2002) Germanium-silicon fractionation in the weathering environment. Geochim Cosmochim Acta 66(9):1525-1537. https://doi.org/10. 1016/S0016-7037(01)00869-9

Lane TH, Burns SA (1996) Silica, silicon and silicones...Unraveling the mystery. In: Compans RW, Cooper M, Koprowski H, Melchers F, Oldstone M, Olsnes S, Potter M, Saedler H, Vogt PK, Wagner H, Potter M, Rose NR (eds) Immunology of silicones, vol 210. Springer, Berlin, pp 3-12

Liang Y, Sun W, Zhu YG, Christie P (2007) Mechanisms of silicon-mediated alleviation of abiotic stresses in higher plants: a review. Environ Pollut 147(2):422-428. https:// doi.org/10.1016/j.envpol.2006.06.008

Lugolobi F, Kurtz AC, Derry LA (2010) Germanium-silicon fractionation in a tropical, granitic weathering environment. Geochim Cosmochim Acta 74(4):1294-1308. https://doi.org/10.1016/j.gca.2009.11.027

Ma JF (2003) Functions of silicon in higher plants. In: Müller WEG, Jeanteur P, Kostovic I, Kuchino Y, Macieira-Coelho A, Rhoads RE (eds) Silicon biomineralization. Springer, Berlin, pp 127-147

Ma JF, Yamaji N (2008) Functions and transport of silicon in plants. Cell Mol Life Sci (CMLS) 65(19):3049-3057. https://doi.org/10.1007/s00018-008-7580-X

Ma JF, Miyake Y, Takahashi E (2001) Silicon as a beneficial element for crop plants. In: Studies in plant science, 8th edn. Elsevier, Amsterdam, pp 17-39

Ma JF, Yamaji N, Mitani N, Tamai K, Konishi S, Fujiwara T, Katsuhara M, Yano M (2007) An efflux transporter of silicon in rice. Nature 448(7150):209-212. https://doi.org/ 10.1038/nature05964

Ma JF, Yamaji N, Mitani-Ueno N (2011) Transport of silicon from roots to panicles in plants. Proc Jpn Acad Ser B 87(7):377-385. https://doi.org/10.2183/pjab.87.377

Mann S, Perry CC, Williams RJP, Fyfe CA, Gobbi GC, Kennedy GJ (1983) The characterisation of the nature of silica in biological systems. J. Chem. Soc. Chem. Commun. (4):168. https://doi.org/10.1039/C39830000168

Mitani N, Ma JF, Iwashita T (2005) Identification of the silicon form in xylem sap of rice (Oryza sativa L.). Plant Cell Physiol 46(2):279-283. https://doi.org/10.1093/pcp/ pci018

Mitani N, Chiba Y, Yamaji N, Ma JF (2009) Identification and characterization of maize and barley Lsi2-like silicon efflux transporters reveals a distinct silicon uptake system from that in rice. Plant Cell 21(7):2133-2142. https://doi. org/10.1105/tpc.109.067884

Nikolic M, Nikolic N, Liang Y, Kirkby EA, Romheld V (2006) Germanium- 68 as an adequate tracer for silicon transport in plants. Characterization of silicon uptake in different crop species. Plant Physiol 143(1):495-503. https://doi.org/10. 1104/pp.106.090845

Opfergelt S, Cardinal D, André L, Delvigne C, Bremond L, Delvaux B (2010) Variations of $\delta 30 \mathrm{Si}$ and $\mathrm{Ge} / \mathrm{Si}$ with weathering and biogenic input in tropical basaltic ash soils under monoculture. Geochim Cosmochim Acta 74(1):225-240. https://doi.org/10.1016/j.gca.2009.09.025

Perry CC, Lu Y (1992) Preparation of silicas from silicon complexes. Role of cellulose in polymerisation and aggregation control. J Chem Soc Faraday Trans 88(19):2915. https://doi.org/10.1039/ft9928802915

Piperno DR (2006) Phytoliths: a comprehensive guide for archaeologists and paleoecologists. AltaMira Press, Lanham

Pokrovski GS, Schott J (1998) Experimental study of the complexation of silicon and germanium with aqueous organic species: implications for germanium and silicon transport and $\mathrm{Ge} / \mathrm{Si}$ ratio in natural waters. Geochim Cosmochim Acta 62(21-22):3413-3428. https://doi.org/10.1016/ S0016-7037(98)00249-X

Pontigo S, Ribera A, Gianfreda L, de la Luz MM, Nikolic M, Cartes P (2015) Silicon in vascular plants: uptake, transport and its influence on mineral stress under acidic conditions. Planta 242(1):23-37. https://doi.org/10.1007/s00425-0152333-1

Qin T, Gutu T, Jiao J, Chang C-h, Rorrer GL (2008) Biological fabrication of photoluminescent nanocomb structures by metabolic incorporation of germanium into the biosilica of the diatom Nitzschia frustulum. ACS Nano 2(6):1296-1304. https://doi.org/10.1021/nn800114q

Rains DW, Epstein E, Zasoski RJ, Aslam M (2006) Active silicon uptake by wheat. Plant Soil 280(1-2):223-228. https://doi.org/10.1007/s11104-005-3082-x

Reimann C, Siewers U, Tarvainen T (2003) Agricultural soils in Northern Europe. A geochemical atlas: numerous figures and tables and one CD-ROM. Geologisches Jahrbuch Sonderhefte Reihe D, Mineralogie, Petrographie, Geochemie, Lagerstättenkunde, Heft SD 5. In Kommission E. Schweizerbart'sche Verlagsbuchhandlung (Nägele u. Obermiller), Stuttgart

Sahebi M, Hanafi MM, Siti Nor Akmar A, Rafii MY, Azizi P, Tengoua FF, Nurul Mayzaitul Azwa J, Shabanimofrad M (2015) Importance of silicon and mechanisms of biosilica formation in plants. Biomed Res Int 2015:396010. https:// doi.org/10.1155/2015/396010

Sato K, Ozaki N, Nakanishi K, Sugahara Y, Oaki Y, Salinas C, Herrera S, Kisailus D, Imai H (2017) Effects of nanostructured biosilica on rice plant mechanics. RSC Adv 7(22):13065-13071. https://doi.org/10.1039/c6ra27317c

Scribner AM, Kurtz AC, Chadwick OA (2006) Germanium sequestration by soil. Targeting the roles of secondary clays and Fe-oxyhydroxides. Earth Planet Sci Lett 243(3-4):760-770. https://doi.org/10.1016/j.eps1.2006.01. 051

Shannon RD (1976) Revised effective ionic radii and systematic studies of interatomic distances in halides and chalcogenides. Acta Crystallogr A 32(5):751-767. https://doi. org/10.1107/S0567739476001551

Sommer M, Kaczorek D, Kuzyakov Y, Breuer J (2006) Silicon pools and fluxes in soils and landscapes - a review. J Plant 
Nutr Soil Sci 169:310-329. https://doi.org/10.1002/jpln. 200521981

Soukup M, Martinka M, Cigan M, Ravaszova F, Lux A (2014) New method for visualization of silica phytoliths in Sorghum bicolor roots by fluorescence microscopy revealed silicate concentration-dependent phytolith formation. Planta 240(6):1365-1372. https://doi.org/10.1007/s00425014-2179-y

Soukup M, Martinka M, Bosnic D, Caplovicová M, Elbaum R, Lux A (2017) Formation of silica aggregates in sorghum root endodermis is predetermined by cell wall architecture and development. Ann Bot 120(5):739-753. https://doi. org/10.1093/aob/mcx060

Sparks JP, Chandra S, Derry LA, Parthasarathy MV, Daugherty CS, Griffin R (2011) Subcellular localization of silicon and germanium in grass root and leaf tissues by SIMS: evidence for differential and active transport. Biogeochemistry 104(1-3):237-249. https://doi.org/10.1007/s10533010-9498-2

Street-Perrott FA, Barker PA (2008) Biogenic silica: a neglected component of the coupled global continental biogeochemical cycles of carbon and silicon. Earth Surf Process Landforms 33(9):1436-1457. https://doi.org/10.1002/esp. 1712

Tamai K, Ma JF (2003) Characterization of silicon uptake by rice roots. New Phytol 158(3):431-436. https://doi.org/10. 1046/j.1469-8137.2003.00773.x

Tensho K, Yeh K-L (1972) Tracer study on preferential uptake of germanium by rice plant. Soil Sci Plant Nutr 18(5):173-178. https://doi.org/10.1080/00380768.1972. 10432501

Trembath-Reichert E, Wilson JP, McGlynn SE, Fischer WW (2015) Four hundred million years of silica biomineralization in land plants. Proc Natl Acad Sci USA 112(17):5449-5454. https://doi.org/10.1073/pnas. 1500289112

Twiss PC, Suess E, Smith RM (1969) Morphological classification of grass phytoliths. Soil Sci Soc Am J 33(1):109. https://doi.org/10.2136/sssaj1969. 03615995003300010030x

White AF, Vivit DV, Schulz MS, Bullen TD, Evett RR, Aagarwal J (2012) Biogenic and pedogenic controls on Si distributions and cycling in grasslands of the Santa Cruz soil chronosequence, California. Geochim Cosmochim Acta 94:72-94. https://doi.org/10.1016/j.gca.2012.06.009

Wiche O (2016) Plant availability of germanium and rare earth elements in soils. Dissertation, TU Bergakademie Freiberg

Wiche O, Heilmeier H (2016) Germanium (Ge) and rare earth element (REE) accumulation in selected energy crops cultivated on two different soils. Miner Eng 92:208-215. https://doi.org/10.1016/j.mineng.2016.03.023
Wiche O, Székely B, Kummer N-A, Moschner C, Heilmeier H (2016) Effects of intercropping of oat (Avena sativa L.) with white lupin (Lupinus albus L.) on the mobility of target elements for phytoremediation and phytomining in soil solution. Int J Phytoremed 18(9):900-907. https://doi. org/10.1080/15226514.2016.1156635

Wiche O, Zertani V, Hentschel W, Achtziger R, Midula P (2017) Germanium and rare earth elements in topsoil and soil-grown plants on different land use types in the mining area of Freiberg (Germany). J Geochem Explor 175:120-129. https://doi.org/10.1016/j.gexplo.2017.01. 008

Wiche O, Székely B, Moschner C, Heilmeier H (2018) Germanium in the soil-plant system-a review. Environ Sci Pollut Res Int 25:31938. https://doi.org/10.1007/s11356018-3172-y

Wu J-W, Shi Y, Zhu Y-X, Wang Y-C, Gong H-J (2013) Mechanisms of enhanced heavy metal tolerance in plants by silicon. A review. Pedosphere 23(6):815-825. https:// doi.org/10.1016/S1002-0160(13)60073-9

Yamaji N, Ma JF (2009) A transporter at the node responsible for intervascular transfer of silicon in rice. Plant Cell 21(9):2878-2883. https://doi.org/10.1105/tpc.109.069831

Yamaji N, Ma JF (2011) Further characterization of a rice silicon efflux transporter, Lsi2. Soil Sci Plant Nutr 57(2):259-264. https://doi.org/10.1080/00380768.2011. 565480

Yamaji N, Mitatni N, Ma JF (2008) A transporter regulating silicon distribution in rice shoots. Plant Cell 20(5):1381-1389. https://doi.org/10.1105/tpc.108.059311

Yamaji N, Chiba Y, Mitani-Ueno N, Feng Ma J (2012) Functional characterization of a silicon transporter gene implicated in silicon distribution in barley. Plant Physiol 160(3):1491-1497. https://doi.org/10.1104/pp.112.204578

Yan G-C, Nikolic M, Ye M-J, Xiao Z-X, Liang Y-C (2018) Silicon acquisition and accumulation in plant and its significance for agriculture. J Integr Agric 17(10):2138-2150. https://doi.org/10.1016/S2095-3119(18)62037-4

Yoshida S, Ohnishi Y, Kitagishi K (1962) Histochemistry of silicon in rice plant. Soil Sci Plant Nutr 8(2):1-5. https:// doi.org/10.1080/00380768.1962.10430982

Zhang C, Kang H, Lv K, Chen H, Yuan S (2011) Maize phytoliths and photoluminescent silica nanotubes prepared from a natural silica resource. Ind Eng Chem Res 50(22):12521-12526. https://doi.org/10.1021/ie2003768

Publisher's Note Springer Nature remains neutral with regard to jurisdictional claims in published maps and institutional affiliations. 